JOURNAL OF THE SOCIETY OF ARCHITECTURAL HISTORIANS VOLUME 76 | NUMBER 2 | JUNE 2017
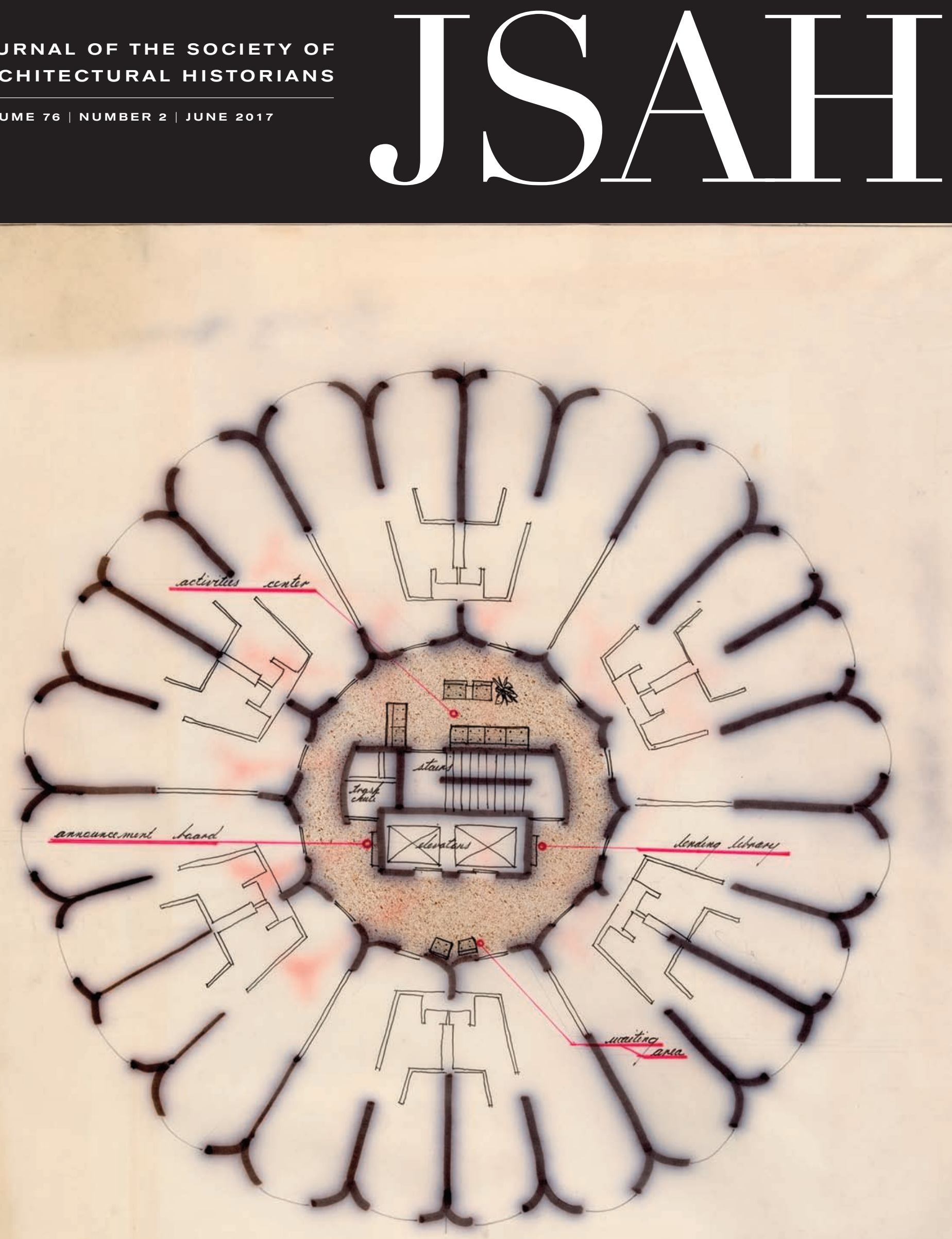

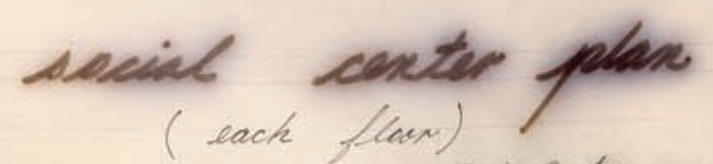

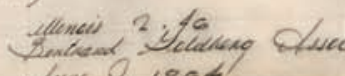


JOURNAL OF THE SOCIETY OF ARCHITECTURAL HISTORIANS

VOLUME 76 | NUMBER 2 | JUNE 2017

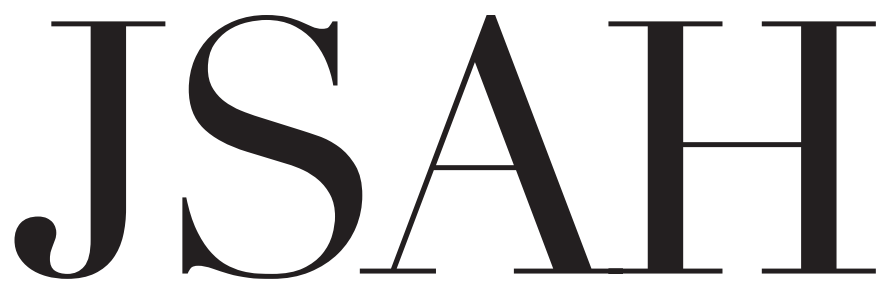

Fournal of the Society of Architectural Historians (FSAH) (ISSN 0037-9808, e-ISSN 2150-5926) is published four times a year (March, June, September, December) for the Society of Architectural Historians by University of California Press, 155 Grand Avenue, Suite 400, Oakland, CA 94612. Periodicals postage paid at Oakland, Calif., and additional mailing offices. POSTMASTER: Send address changes to 7SAH, University of California Press, 155 Grand Avenue, Suite 400, Oakland, CA 94612. Email: customerservice@ucpress.edu.

FSAH also appears in an online, multimedia edition. $7 S A H$ online presents the same text content, but with an expanded illustration program.

To propose a manuscript for publication, or to submit a book, multimedia work, or exhibition for review, consult the instructions at www.sah.org.

\section{Membership Information}

Individual membership to the Society of Architectural Historians is $\$ 135 /$ electronic or $\$ 145 /$ print per calendar year, $\$ 65 /$ electronic or $\$ 75 /$ print per year for students. Go to www.sah.org for more information.

See jsah.ucpress.edu/content/subscriptions-and-single-issues for single issue and institutional sub-scription orders, back issues from volume 65 forward, and claims information. Domestic claims for nonreceipt of issues should be made within 90 days of the mail date; overseas claims within 180 days. Mail dates can be checked at: www.ucpress.edu/journals.php? $\mathrm{p}=$ release. UC Press does not begin accepting claims for an issue until thirty (30) days after the mail date. To order issues prior to volume 65, contact membership@sah.org.

Inquiries about advertising can be sent to adsales@ucpressjournals.com. For complete abstracting and indexing coverage for the journal, please visit jsah.ucpress. edu. All other inquiries can be directed to customerservice@ucpress.edu.

Copying and permissions notice: Authorization to copy article content beyond fair use (as specified in Sections 107 and 108 of the U.S. Copyright Law) for internal or personal use, or the internal or personal use of specific clients, is granted by The Regents of the University of California on behalf of the Society of Architectural Historians for libraries and other users, provided that they are registered with and pay the specified fee through the Copyright Clearance Center (CCC), www.copyright.com. To reach the CCC's Customer Service Department, phone 978-750-8400 or write to info@copyright.com. For permission to distribute electronically, republish, resell, or repurpose material, use the CCC's Rightslink service, available at jsah.ucpress.edu/content/permissions. Submit all other permissions and licensing inquiries through University of California Press's Reprints and Permissions web page, www.ucpress.edu/journals.php? $p=$ reprints, or via email: jpermissions@ucpress.edu.

SAH gratefully acknowledges the home institutions of the editors for their support of JSAH. The SAH Scott Opler Endowment for New Scholars provides funds to support publication by emerging scholars in $7 S A H$ and a $7 S A H$ editorial assistant's position.

Front cover: Bertrand Goldberg, "Social Center Plan," floor plan for elderly housing, 1964, ink and marker on paper, $84 \times 86$ centimeters; handwriting on the plan indicates space for an activities center at top, lending library at right, writing area at bottom, and announcement board at left (Raymond Hilliard Center, Chicago, Archive of Bertrand Goldberg, gifted by his children through his estate, RX23664/107.108, Art Institute of Chicago) (see page 228).

Printed by The Sheridan Press

(C) 2017 Society of Architectural Historians. All rights reserved.
Editor

Patricia A. Morton

Department of the History of Art 900 University Avenue University of California, Riverside

Riverside, CA 92521-0319 patricia.morton@ucr.edu

Editor Designate

Keith Eggener

Department of the History of Art and

Architecture

University of Oregon

5229 University of Oregon

Lawrence Hall 247

Eugene, OR 97403

keggener@uoregon.edu

Book Review Editors

North and South America

Dale Allen Gyure

Department of Architecture

Lawrence Technological University

21000 West Ten Mile Road

Southfield, MI 48075

gyure@1tu.edu

Europe, Africa, and Asia to 1750

John Senseney

Illinois School of Architecture

University of Illinois at Urbana-Champaign

117 Temple Hoyne Buell Hall

611 Lorado Taft Drive, MC-621

Champaign, IL 61820

senseney@illinois.edu

Europe, Africa, and Asia from 1750

Sheila Crane

Department of Architectural History

School of Architecture

University of Virginia

P.O. Box 400122

Charlottesville, VA 22904-4122

scrane@virginia.edu

Exhibition Review Editor

Leslie Topp

Department of History of Art

Birkbeck, University of London

43 Gordon Square

London WC1H 0PD

UK

1.topp@bbk.ac.uk

Multimedia Review Editor

Paulette Singley

School of Architecture

Woodbury University

7500 Glenoaks Boulevard

Burbank, CA 91510-7846

paulette.singley@woodbury.edu

Managing Editor

Kathy Hix

kathyhix2@gmail.com

Copyeditor

Judy Selhorst

Opler Editorial Assistant

Danielle Peltakian 
JOURNAL OF THE SOCIETY OF ARCHITECTURAL HISTORIANS

VOLUME 76 | NUMBER 2 | JUNE 2017

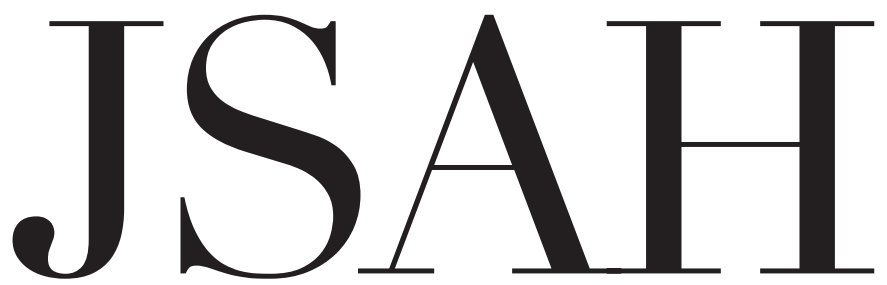

$138 \quad$ In This Issue

\section{Editorial}

139 Architectural History and the Current Moment

\section{Field Note}

141 The Crisis in Conservation: Istanbul's Gezi Park between Restoration and Resistance CAN BILSEL

\section{Findings}

146 Le Corbusier and the Romanian Cula JUDITH BING

\section{Articles}

154 Contested Space at the Entrance of the Athenian Acropolis JESSICA PAGA

175 The Doors of the Chapel and the Keys to the Palace of Louis IX MEREDITH COHEN

197 Mies's Opaque Cube: The Electric Utilities Pavilion at the 1929 Barcelona International Exposition LAURA LIZONDO SEVILLA

218 Integration by Design: Bertrand Goldberg, Stanley Tigerman, and Public Housing Architecture in Postwar Chicago

MARISA ANGELL BROWN

\section{Books}

239 Roman Architecture in Provence, by James C. Anderson Jr. REVIEWED BY LOUISE REVELL

The Visual Culture of Catholic Enlightenment, by Christopher M. S. Johns REVIEWED BY CAROLE PAUL 
Architecture since 1400, by Kathleen James-Chakraborty; A Critical History of Contemporary Architecture, 1960-2010, edited by Elie G. Haddad and David Rifkind

REVIEWED BY MAX HIRSH

Noab's Ark: Essays on Architecture, by Hubert Damisch

REVIEWED BY JEAN-LOUIS COHEN

Architecture and the Historical Imagination: Eugène-Emmanuel Viollet-le-Duc, 1814-1879, by Martin Bressani

REVIEWED BY SEAN WEISS

Practicing Utopia: An Intellectual History of the New Town Movement, by Rosemary Wakeman REVIEWED BY M. CHRISTINE BOYER

Essays in Early American Architectural History: A View from the Chesapeake, by Carl R. Lounsbury REVIEWED BY CLIFTON ELLIS

Building Zion: The Material World of Mormon Settlement, by Thomas Carter REVIEWED BY RYAN K. SMITH

Dark Space: Architecture, Representation, Black Identity, by Mario Gooden

REVIEWED BY AMBER WILEY

\section{Exhibitions}

255 Nella mente di Vincenzo Scamozzi: Un intellettuale architetto al tramonto del rinascimento REVIEWED BY DARIO DONETTI

Friedrich Kiesler: Lebenswelten/Life Visions

REVIEWED BY MONIKA PLATZER

Radical Design

REVIEWED BY MARIE THERES STAUFFER

Engineering the World: Ove Arup and the Philosophy of Total Design

REVIEWED BY ANDREW SAINT

Archaeology of the Digital: Complexity and Convention

REVIEWED BY MATTHEW ALLEN

\section{Multimedia}

Canadian Centre for Architecture Website REVIEWED BY JESSICA VARNER 


\title{
Mies's Opaque Cube: The Electric Utilities Pavilion at the 1929 Barcelona International Exposition
}

\author{
LAURA LIZONDO SEVILLA \\ Universitat Politècnica de València
}

T he pavilion that Ludwig Mies van der Rohe designed for Germany's Electric Utilities at the 1929 Barcelona International Exposition was white on the outside and paneled on the inside (Figure 1). Bare on the outside, dressed on the inside. Tangible on the outside, virtual on the inside. A magical, opaque box filled with a surprising world of illusion featuring the latest technology of that time. Finite on the outside, "infinite" on the inside. A dihedron outside, blurred boundaries inside. This opaque cube was the only building that Mies built as a solid, closed unit, the only building he created in which the nature of the materials employed was entirely hidden, inside and out. ${ }^{1}$ It is a virtually forgotten building that, despite seeming to be the exception that proves the rule, Mies used to experiment with a variety of concepts that he subsequently featured in his American buildings.

Architecture of this kind finds "its way into "how we as a rule see, feel, perceive, imagine, and understand' and is thus an integral part of a coherent interpretation of the world and of ourselves." In these terms, Fritz Neumeyer describes the ways in which the architect's work affects how humans experience the world. Within this conception, architecture-in the sense of both an art form and a language-is regarded as a vehicle for meaning, a way of building spatial experiences sufficiently powerful to make people connect with their inner selves.

Neumeyer, noted for his deep-rooted philosophical criticism of Mies's work and thought, explains the spatial quality of Miesian buildings on the basis of the sensory and intellectual

Journal of the Society of Architectural Historians 76, no. 2 (June 2017), 197-217, ISSN 0037-9808, electronic ISSN 2150-5926. (C) 2017 by the Society of Architectural Historians. All rights reserved. Please direct all requests for permission to photocopy or reproduce article content through the University of California Press's Reprints and Permissions web page, http://www.ucpress.edu/ journals.php?p=reprints, or via email: jpermissions@ucpress.edu. DOI: https:// doi.org/10.1525/jsah.2017.76.2.197.

experience they inspire in the spectator-inhabitant. ${ }^{3}$ As Neumeyer describes it, a semiopen, semiclosed, fluid space was typical of Mies's works in Germany. This type of space blurs spatial boundaries, confusing the senses and forming areas that seem to change constantly. According to Neumeyer, the beholder's perception changes, not the space. The individual's physical movement breathes meaning into the awareness of architectural space. ${ }^{4}$

In his Berlin period, Mies experimented with blurring architectonic boundaries in his "paper buildings" and his works for exhibitions. ${ }^{5} \mathrm{He}$ managed to eliminate spatial constraints to a considerable extent by toying with the visual and constructive properties of materials, as he did in the Glass Room for the exhibition The Dwelling (Stuttgart, 1927). He created interconnected, geometric spaces, as in the Velvet and Silk Café for the exhibition Women's Fashion (Berlin, 1927). He produced a mazelike movement delimited by an open plan, as in the German Pavilion for the 1929 Barcelona International Exposition and the Exhibition House for The Dwelling in Our Time (Berlin, 1931). At the same time that Mies worked on the concept of a fluid space, he researched the sensations caused by a sealed, empty space. He developed this aspect in the Electric Utilities Pavilion (also known as the Electricity Supply Company Pavilion), a remarkable project that I call "Mies's opaque cube."

My study of this unique Miesian project was far from an easy matter. ${ }^{6}$ Extant original documentation is very scarce and is found in just four sources. The first source consists of five photographs: three by Wilhelm Niemann, the owner of Berliner Bild-Bericht, one of Berlin's leading advertising agencies in the 1920s; one taken by E. Blum and published in Die Linse, September 1929; and one found in technical brochures about linoleum produced by the company Deutsche Linoleum-Werke AG. The second source is the 


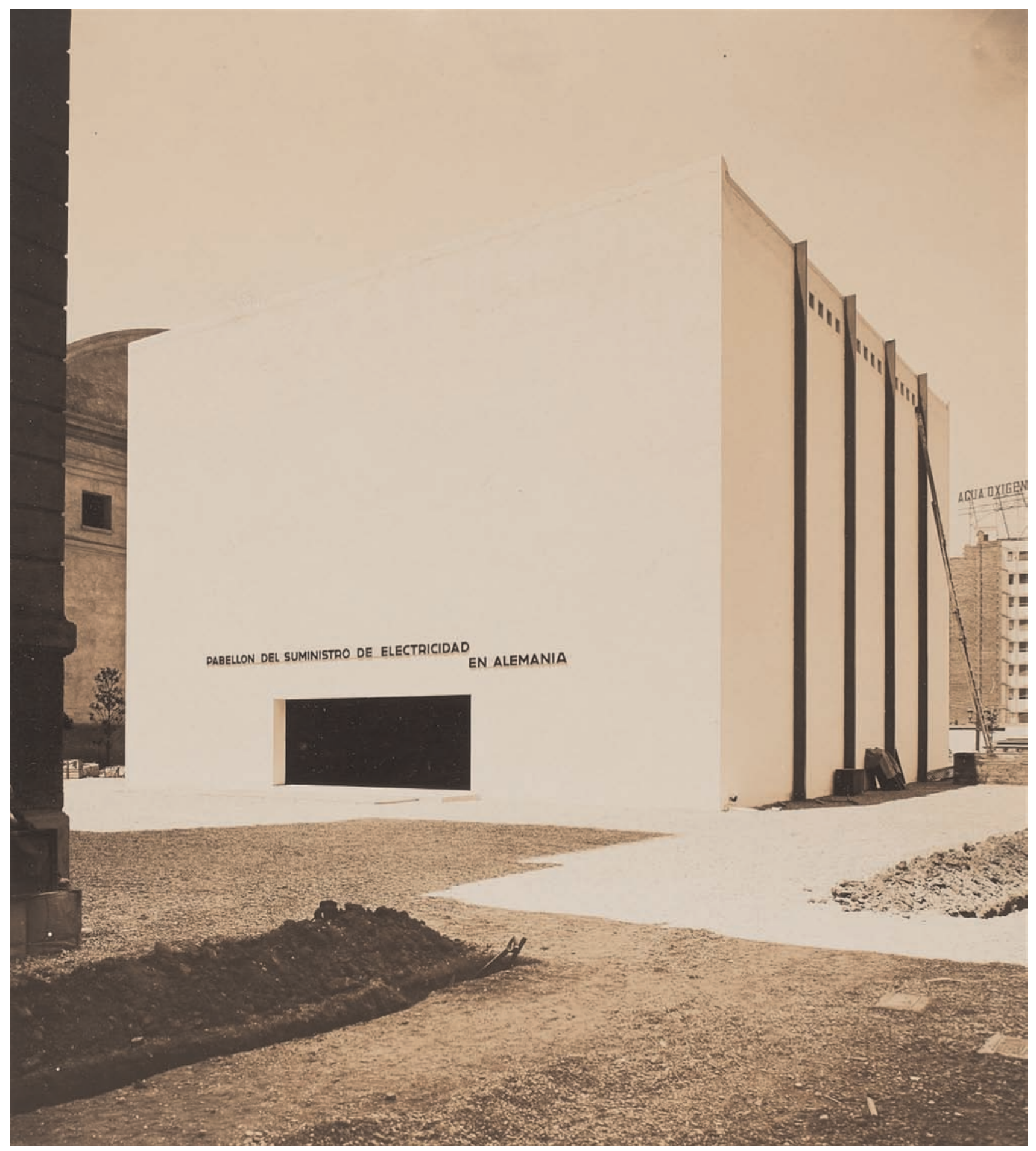

Figure 1 Ludwig Mies van der Rohe, Electric Utilities Pavilion, Barcelona International Exposition, 1929 (photo by Berliner Bild-Bericht; Klassik Stiftung Weimar, Bauhaus Museum, loan from a private collector; @ Mies van der Rohe, VEGAP, Spain, 2017).

correspondence between Mies and Fritz Schüler, the engineer who contributed to the interior design of the pavilion, which is now housed in the Mies van der Rohe Archive at New York's Museum of Modern Art. The third source consists of the occasional passing references to the Electric Utilities Pavilion found in the official journal of the Barcelona Exposition, Diario Oficial de la Exposición Internacional de Barcelona 1929-1930, copies of which are housed in the Biblioteca Nacional de España. The last surviving source is the official catalogue of the pavilion, titled La Economía Eléctrica en Alemania/Deutscblands Elektrizitätswirtschaft/Electricity Supply in Germany, which provides little information about the architecture of the building. ${ }^{8}$ 
Apart from these documents, none of the original plans or drawings of the building have survived, nor are any reproductions of its plan known to have been published. Nor is there any record of any verbal or written mention of this building by Mies himself. The pavilion, practically hidden between the Communications and Transport Palace and the Textile Industry Palace, went unnoticed by the architecture critics of the time. An ephemeral building designed, built, and demolished in a short space of time, the Electric Utilities Pavilion, despite being loaded with meaning, was discreet. It provided outward sobriety for a container designed to showcase the greatness of Germany's electrical industry. It was architecture as a vehicle for an idea. The pavilion's scale and opacity provided proportions and form in keeping with its setting, which included the Communications and Transport Palace and the Textile Industry Palace built alongside it. This is scant material indeed, but enough to reexamine the part played by this forgotten, opaque cube in the architecture of Ludwig Mies van der Rohe.

\section{History of the Commission}

It is very curious how buildings come to pass. Germany had the task of putting on an exhibition at Barcelona. One day I received a call from the German Government. I was told that the French and the British would have a pavilion and Germany should have a pavilion too. I said: "What is a pavilion? I haven't the slightest idea." I was told: "We need a pavilion. Design it, and not too much class!" I must say it was the most difficult work which ever confronted me, because I was my own client; I could do what I liked. But I did not know what a pavilion should be. Looking back over all these years I can remember it very well. It was strange. ${ }^{9}$

This is how Mies remembered his immediate reaction when he was commissioned to design a pavilion to represent Germany at the 1929 Barcelona International Exposition, a building now often simply called the Barcelona Pavilion. He described it as a challenge, a fast, low-budget, emblematic project with no program that came about at the last minute in competition with other countries. Mies's first commission from the German government for the Barcelona exposition, however, was not the pavilion to represent Germany, but the design and staging of the German industry exhibits and a trade pavilion for Germany's electrical industry. ${ }^{10}$

Mies's success as the organizer and designer of the 1927 Weissenhof exhibition in Stuttgart was a decisive factor in his appointment to design the German contributions to the Barcelona International Exposition. In addition, his architecture embodied the image that Germany wanted to convey to the world: that of a prosperous, culturally productive country whose society championed the new values of modernity. Mies's commitment to modern architecture and progress tallied perfectly with the government's aim to play a leading role in this exhibition that would be equivalent to Germany's early twentieth-century prominence in technology, the arts, sciences, and thought. ${ }^{11}$

Mies's correspondence and the dates of his drawings reveal that he accepted the commissions enthusiastically and with remarkable speed. The decision of the German government to build a ceremonial reception area for its industrial exhibits was made as late as the summer of 1928 , and the first drawings found in the MoMA Mies van der Rohe Archive date from early November of that year. ${ }^{12}$ In a short space of time he produced myriad drawings for both the Barcelona Pavilion and the industrial exhibition halls. Mies did not work alone, however. A good deal of the credit given to Mies for this exhibition was due to the designer Lilly Reich. Reich was a well-known designer of interiors and exhibitions who had been a member of the German Werkbund since 1912. She worked in close conjunction with Mies from 1926 onward, until Mies immigrated to the United States in $1937 .{ }^{13}$ In her capacity as the artistic director of the industry exhibits, Reich freed Mies from building them and fitting them out, allowing him to concentrate on designing the items requiring more architectural skill—that is, the pavilions. Reich managed and organized the selection of products submitted by more than three hundred companies, arranged the location of each product, and designed every layout, including much of the display equipment itself. In other words, she was responsible not only for the overall structure and design of the display stands but also for their details, which entailed the choices of materials, colors, and finishes.

Reich worked on exhibitions and other designs with Mies for more than a decade. During that period, Mies theorized and experimented with the fundamental concepts that marked his subsequent architectural strategies. To that end, he used exhibitions as project workshops in which he could actually build his architectural ideas, unfettered by the inherent constraints of permanent architecture. His professional relationship with Reich was fruitful, resulting in a total of more than eighty exhibition projects. ${ }^{14}$ Despite the importance of this professional relationship, few critics have taken a close look at how Reich may have influenced Mies, it being far more usual to consider Mies's influence on Reich. A brief look at their individual careers reveals basic events of interest. In 1926, the year that they began working together, Mies's career blossomed. Until then, he had not worked on exhibitions, whereas Reich had already designed several showcases and had organized and designed more than a dozen exhibitions. ${ }^{15}$

The only time that Mies and Reich worked together physically in the same place was at the Barcelona International Exposition. Although they worked with each other for ten years, they maintained separate offices. According to an employee in Mies's office, Sergius Ruegenberg, the industry exhibits for 


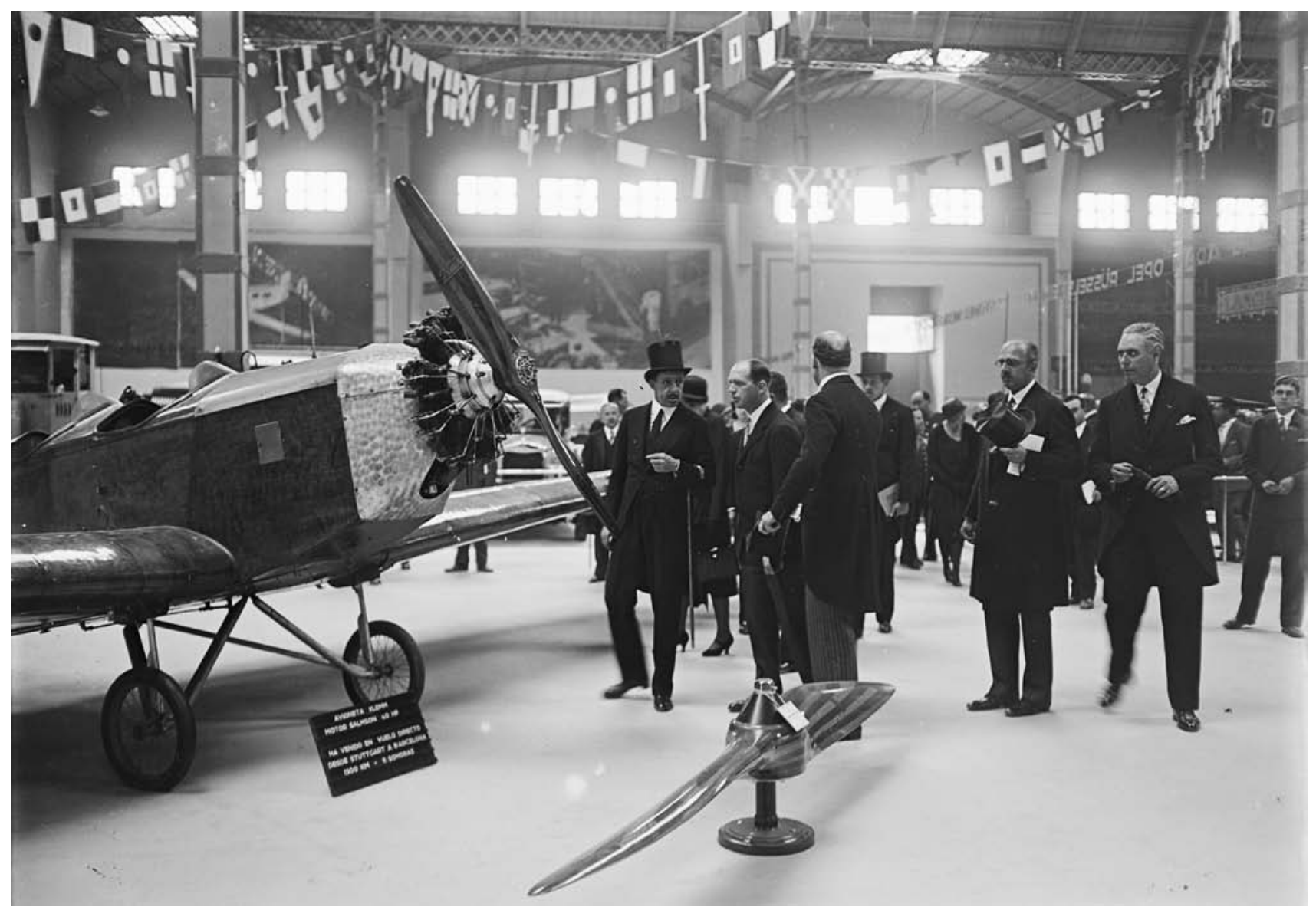

Figure 2 King of Spain, Alfonso XIII (center), and German ambassador Johannes Welczeck (back to the camera) visit the German aerial communication display, designed by Ludwig Mies van der Rohe and Lilly Reich, at the German trade exhibits, Barcelona International Exposition, 1929 (photo by Gaspar-Sagara and Torrents; Josep Maria Sagarra i Plana collection, Arxiu Nacional de Catalunya; @ Generalitat de Catalunya).

Barcelona were developed in office space that Mies rented in a building next to his permanent office. ${ }^{16}$ This new studio was called the Barcelona International Exposition 1929, Construction Department of the German General Commissioner, as can be seen on the stationery used for correspondence during the design and construction phases. ${ }^{17}$ Altogether, Mies and Reich designed twenty-seven exhibition areas for the Barcelona exposition: the national pavilion, the trade pavilion, and twenty-five industry exhibits in thematic areas shared with other countries (Figure 2). It is clear that Mies designed the pavilions himself-apart from the interior design of the Barcelona Pavilion, which he did in association with Reich, and the interior design of the Electric Utilities Pavilion, which he coproduced with Fritz Schüler-but it is not possible to determine how much he contributed to the design of the display stands. The official catalogue of the exposition and most of its official gazettes make no mention of Reich's contribution in Barcelona, unlike the official German catalogue and most of the local and international press releases of that time. Architectural critics Matilda McQuaid and
Sonja Günther believe the stands were mainly the work of Reich and that Mies contributed only to the Hackerbräu beer exhibit, the German textile exhibit, and the German chemistry exhibit. ${ }^{18}$

Not just the literature, but also graphic documents, including photographs and film images of that period, confirm that the trade exhibits were designed by Mies and Reich working as a team. Photographs taken on 26 May 1929, the day of the opening ceremony of the Barcelona Pavilion, show Mies (but not Reich) with the German ambassador, Johannes Welczeck, and the king and queen of Spain, Alfonso XIII and Victoria Eugenia de Battenberg. Mies and Reich did, however, both attend the opening of the trade exhibits: they can be seen behind the royal entourage in a film (now housed in the Catalonia Film Archive) shot on the opening day of the German exhibits (Figure 3). ${ }^{19}$

The extant documentation does not say whether Lilly Reich helped design the Electric Utilities Pavilion. The evidence merely shows that it was designed by Mies in conjunction with the engineer Fritz Schüler, as revealed by correspondence 

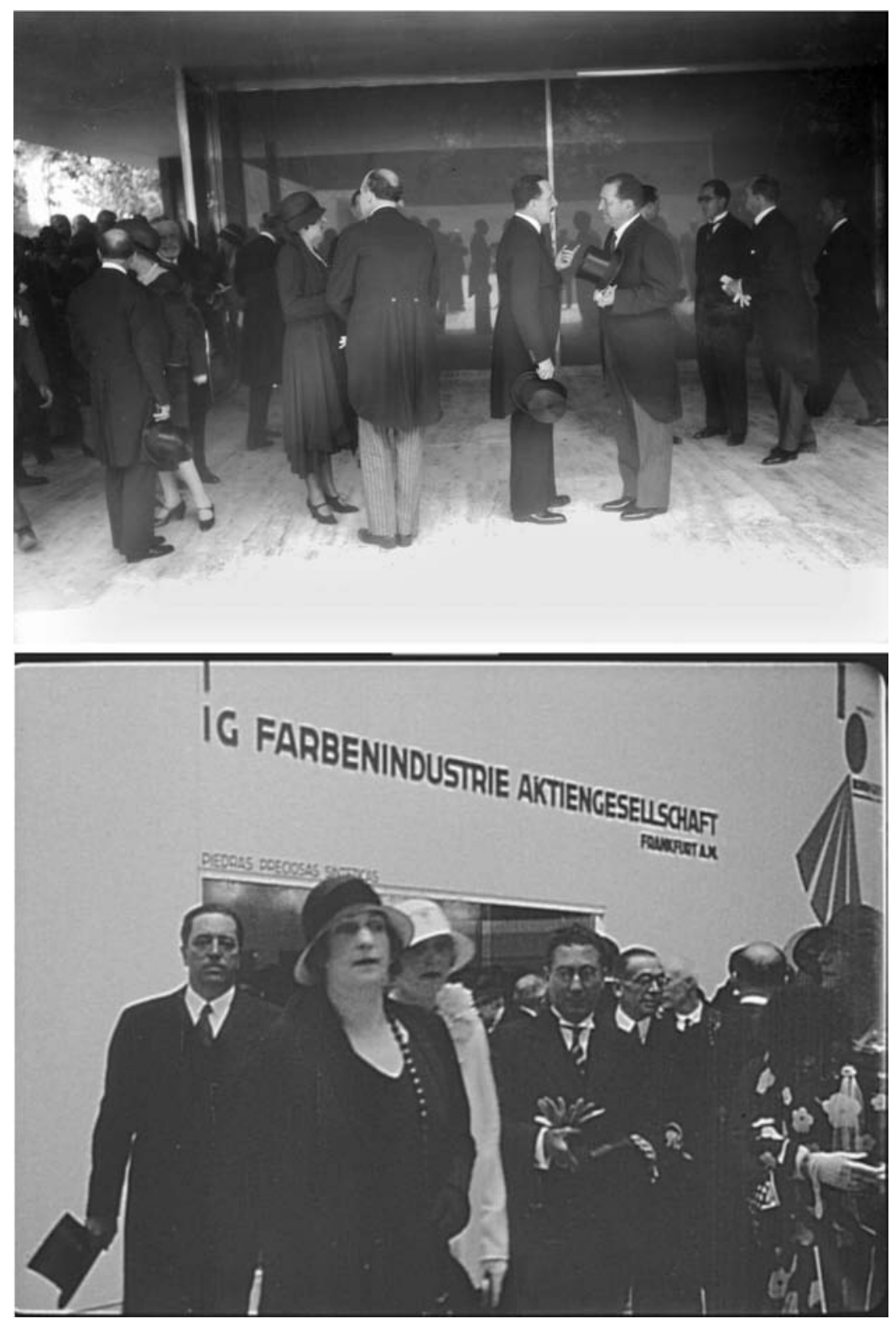

Figure 3 Top: Ludwig Mies van der Rohe (center right), speaking with King Alfonso XIII of Spain (center left), German ambassador Johannes Welczeck (back to the camera), and the queen of Spain, Victoria Eugenie of Battenberg, on the occasion of the opening ceremony of the German Pavilion, Barcelona International Exposition, 26 May 1929 (photo by Brangulí; Brangulí [Fotògrafs], Arxiu Nacional de Catalunya; (c) Generalitat de Catalunya). Bottom: Mies and Lilly Reich at the opening of the German trade exhibits, Barcelona International Exposition, 1929 (film stills by Ramón de Baños; Exposición Internacional de 1929,

Filmoteca de Catalunya, Arxiu Històric de la Ciutat de Barcelona; (c) Arxiu Històric de la Ciutat de Barcelona) between Mies and Schüler. Although Reich may have influenced Mies's interior decorating-regarding, for example, his choices of fabrics, furniture, colors, and so on-there is no indication that she contributed to the architectural design of the building itself. ${ }^{20}$

\section{Structure of the 1929 Barcelona Exposition Site}

The Barcelona International Exposition took place from 19 May 1929 to 15 January 1930. Rather than proposing an enlargement of the existing city of Barcelona, the urban planning of the exhibition entailed the creation of a new urban hub quite a distance from the city's historical center. The resulting 118-hectare exhibition site became a new, emblematic, and monumental area of the city. The location chosen was Montjuic, a rugged and undeveloped mountain that the public regarded as the Acropolis of Barcelona, "the free mountain ... a garden overlooking the Mediterranean which is our spiritual life, our sanctuary," as the official guide described it. ${ }^{21}$ The decision to build the exhibition on the city's highest point made Barcelona the first city to host a universal exposition on a site that was not flat. Jean-Claude Nicolas Forestier, in association with Nicolau Maria Rubió i Tudurí, carried out the hillside development. ${ }^{22}$ The exhibition center itself was built according to an urban planning project drawn up by the Catalan architect Josep Puig i Cadafalch, one of the last proponents of Spanish modernism and a pioneer of noucentisme. $^{23}$

Puig i Cadafalch's layout, influenced by Otto Wagner's Artibus project for fin de siècle Vienna, included the 


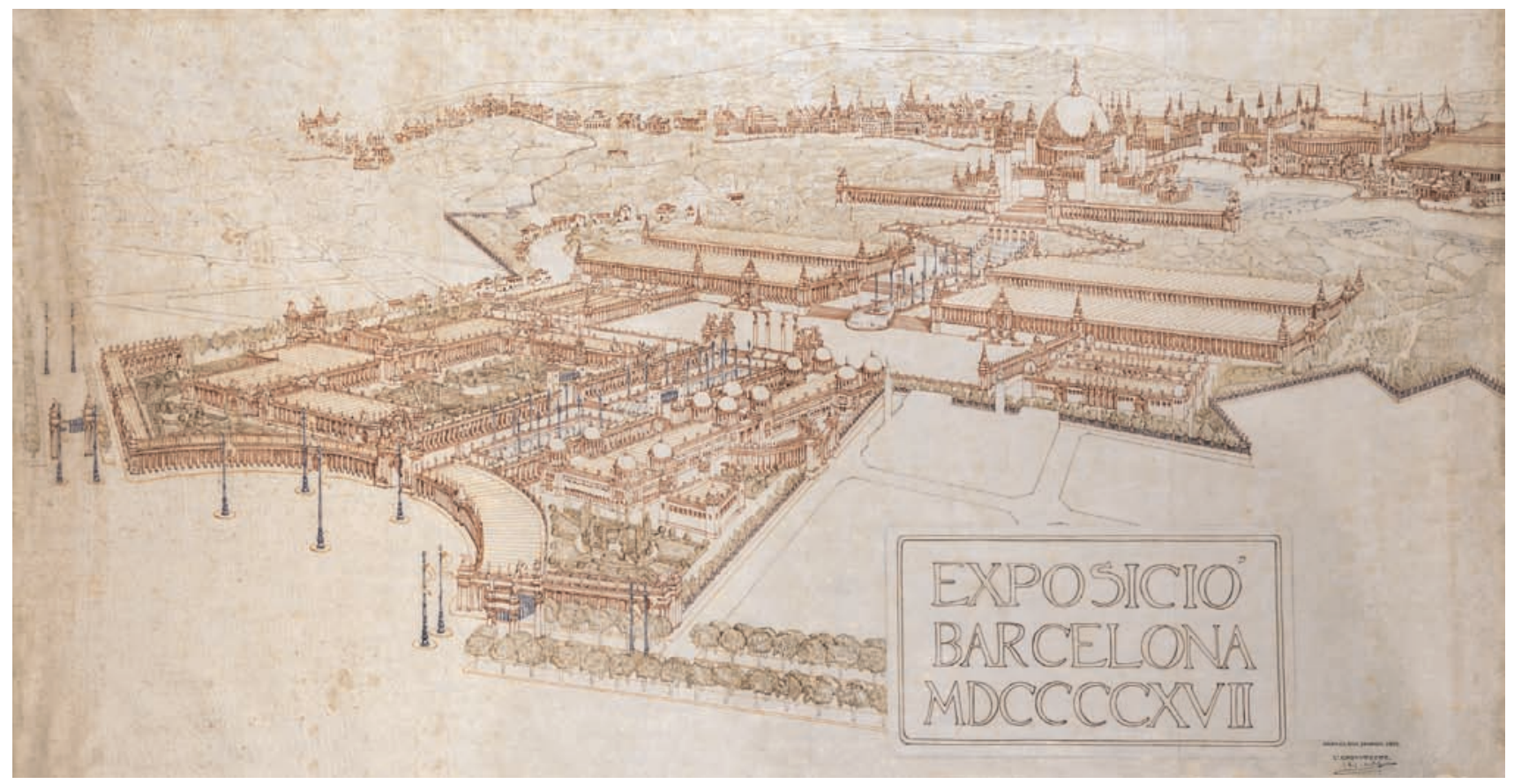

Figure 4 Josep Puig i Cadafalch, urban planning project for Montjuïc, Barcelona, 1917 (Ajuntament de Barcelona: Q162 Planimetria; @ Ajuntament de Barcelona).

construction of a symbolic promenade along the bisection of the angle between Gran Via and Via Paral-lel, two of the most important avenues in Barcelona (Figure 4). This monumental axis aimed to give passersby a new scale with its generous width and sections on different levels, in keeping with the baroque tradition for buildings on slopes, culminating in a central palace topped by a dome. The promenade was crossed by a main road running between two distinct areas: the lower area of the mountain, designated for the official section (the location of the exhibition palaces), and the upper area, to be occupied by the international section (i.e., the representative pavilions of other countries and trade pavilions) (Figure 5). ${ }^{24}$ The lower area began at Plaza de España, a square built by Puig i Cadafalch and Guillem Busquets in 1915 but actually designed by Idelfons Cerdà in 1895 as part of the ensancbe (enlargement) intended to be a thoroughfare linking Barcelona to neighboring towns. Subsequently, and also in 1915, Puig i Cadafalch and Busquets designed a circular monumental ensemble for the plaza positioned around a semicircular baroque colonnade (Figure 6). From Plaza de España, visitors proceeded along Avenida de América past the main exhibition palaces to Plaza de la Mecánica at the bottom of the hill. Situated in the middle of this square were the Torre de la Luz (Tower of Light) and the famous Fuente Mágica (Magic Fountain) of Montjuïc designed by Carles Buiggas, with its entertaining illuminated water jets-a living reminder even today of the 1929 exposition (Figure 7). The upper part of the exhibition center was reached by a flight of steps to the Palau
Nacional and Avinguda dels Montanyans, a thoroughfare perpendicular to the promenade leading to the international section. This was the area where most of the pavilions were located, together with buildings intended for use by the general public, such as the Olympic Stadium, the Foixarda fun fair, and the Spanish Town exhibit.

The main features of Puig i Cadafalch's urban planning were the exedra colonnade that concealed the irregular angles formed by the intersection of old and new roads, the promenade, and Avinguda dels Montanyans, the thoroughfare that connected and highlighted the status of the monumental buildings - the palaces - on the lower area of Montjuïc and the less imposing popular buildings-the pavilions-on its upper slopes. The differences between the palaces and the pavilions went beyond merely their typologies. The palaces housed exhibits of industrial products from the participating nations, while the pavilions represented countries, institutions, or societies. The organization of the exposition site conveyed the different conceptions of the two typologies.

The first difference was one of scale and impact on the urbanized area. The palaces were large buildings covering between 5,000 and 30,000 square meters (Figure 8). ${ }^{25}$ The size and monumental nature of these buildings made them extremely prominent in the exhibition center. Their importance depended not so much on their individual image or style but rather on the sequential rhythms of space and composition that they created in the urban area of the exhibition itself. Therefore, the main lines of the palaces formed the 


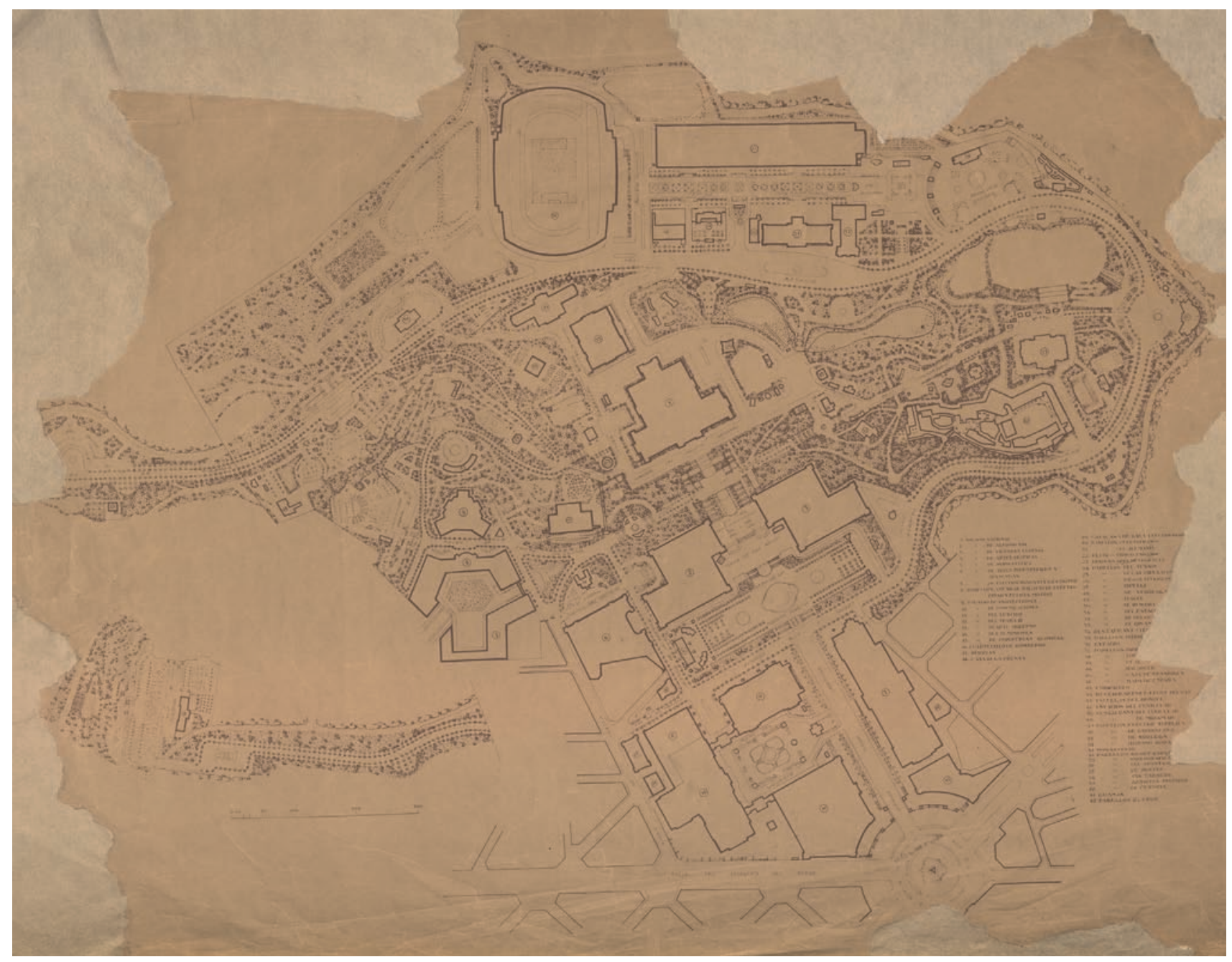

Figure 5 Josep Puig i Cadafalch, plan of the Barcelona International Exposition, 1929 (Plans, Arxiu Historic Ciutat de Barcelona; @ Arxiu Historic Ciutat de Barcelona).

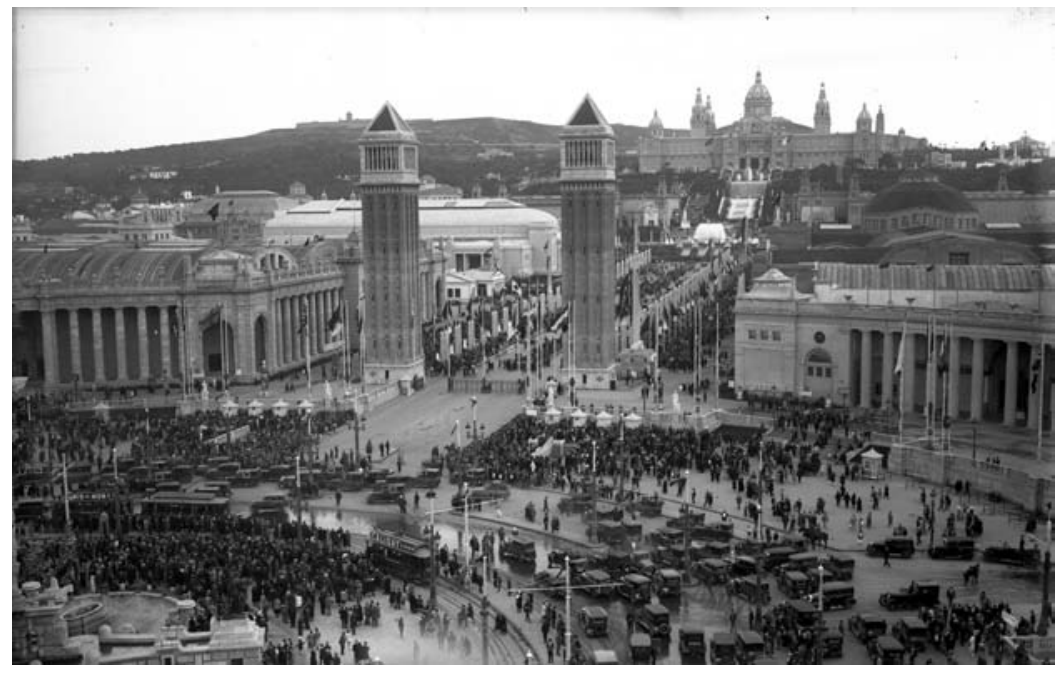

Figure 6 Josep Puig i Cadafalch and Guillem Busquets, Plaza de España, 1915, view during the Barcelona International Exposition, 1929 (photo by J. S. Villanueva; Fuerzas Eléctricas de Cataluña, S.A.; @ Fondo Histórico de Endesa). 
Figure 7 Carles Buïgas, Fuente Mágica and Torre de la Luz, Barcelona International Exposition, 1929 (photo by Ramon Claret and Joan Bert; Bert i Claret [Fotoperiodistes], Arxiu Nacional de Catalunya;

(C) Generalitat de Catalunya).
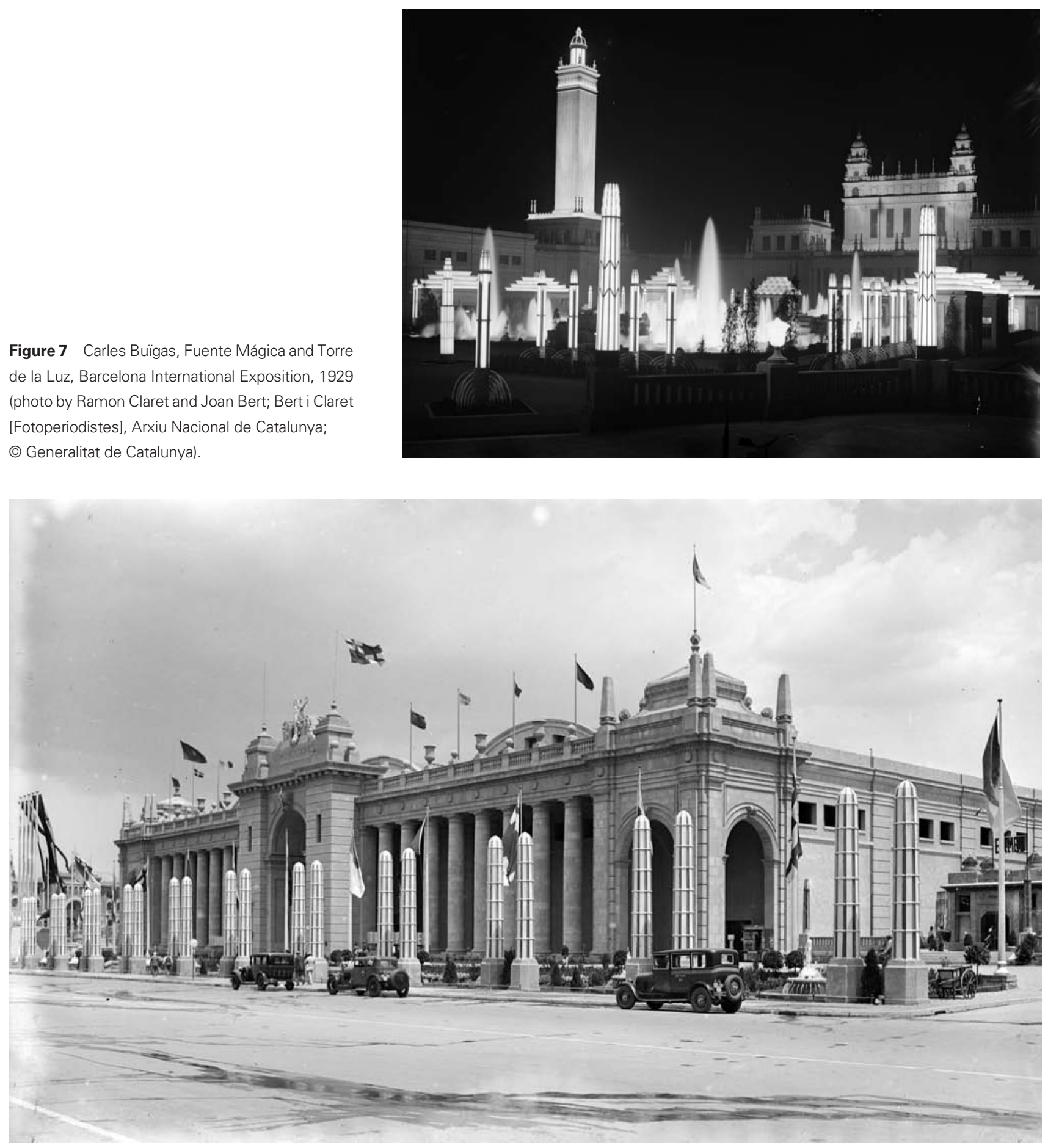

Figure 8 Amadeu Llopard and Alexandre Soler i March, Palace of Metallurgy, Barcelona International Exposition, 1929 (photo by Ramon Claret and Joan Bert; Bert i Claret [Fotoperiodistes], Arxiu Nacional de Catalunya; @ Generalitat de Catalunya).

central axes around which the exhibition was organized (see Figure 5). The pavilions, on the other hand, were much smaller buildings representing countries or companies, and their urban layout was sometimes not well structured (Figure 9). The pavilions not situated in the international section were located in the spaces left over between the exhibition palaces. Far from being a minor detail, this led to designs for many pavilions that treated them as isolated and formally independent objects, commensurate with their programs but paying little attention to the surrounding architecture and planning.

In addition to these differences of form, the palaces and pavilions had disparate functions. Whereas the palaces were designed as neutral containers to house items of various types and 


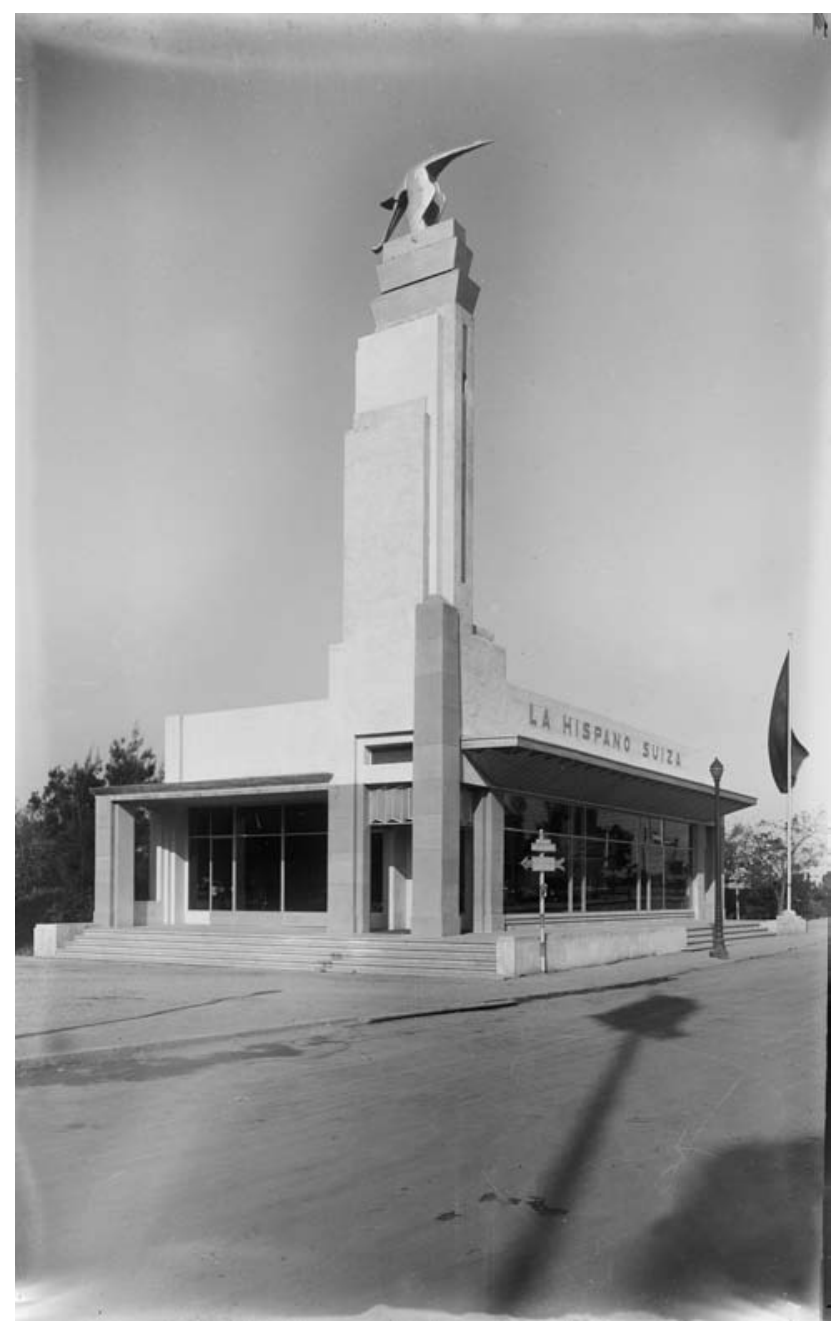

Figure 9 Eusebi Bona i Puig, Hispano-Swiss Pavilion, Barcelona International Exposition, 1929 (photo by Gabriel Casas i Galobardes; Gabriel Casas i Galobardes collection, Arxiu Nacional de Catalunya; (c) Núria Casas i Formiguera).

provenances, the pavilions were designed in response to their specific exhibits. Consequently, the contents of the pavilions were controlled precisely, and the designs of these buildings were linked from the outset to the messages the organizers wanted to convey. These pavilions had a certain coherence between container and contents, outside and interior, and language and message.

This differentiation of function and language evokes a third variation. The two types of buildings differed greatly in regard to technology and materials. The palaces were not temporary buildings, but were made of permanent and unchanging materials able to give shape to the sense of monumentality. Indeed, most of these palaces still exist today and continue to operate in ways similar to their original functions. The pavilions, however, were designed within a framework of material and conceptual experimentation, an inherent characteristic of ephemeral buildings. Since the intention was to dismantle these buildings shortly after the end of the exhibition, more daring, imaginative, and groundbreaking architecture could be employed.

The pavilions themselves were of two types: those representing countries, the national pavilions, and those representing companies or industries, the trade pavilions. Generally, the national pavilions featured avant-garde but moderate architecture reminiscent, in some instances, of the vernacular language of their respective countries. This architectural modernity was officially represented at the 1929 Barcelona International Exposition by the national pavilions of Sweden, Yugoslavia (Figure 10), Hungary, and France, along with Germany's legendary pavilion. The trade pavilions, in contrast, were not subjected to institutional oversight and featured a far bolder blend of architectonic languages-languages that intermingled traits borrowed from "high" architectonic culture with "low" elements typical of the popular world of the masses and leisure. The ensuing imagery, spectacle, and consumerism of the nonstate-sponsored pavilions brought visitors face-to-face with a far more imaginative type of architecture that often toyed with fiction. ${ }^{26}$ Examples of such pavilions were the Barcelona Savings Bank Pavilion, the Philippine Tobacco Company Pavilion, the Calcetines Molfort's (a sock manufacturer) Pavilion, the Sociedad Anónima Uralita (a roofing materials manufacturer) Pavilion, the Spanish Tourist Board Pavilion, the CSHE (Ebro Water Authority) Pavilion (Figure 11), and the German Electric Utilities Pavilion, the building under study here.

\section{The External Purism of the German Electric Utilities Pavilion}

We reject everything angular, everything dark, everything overelaborate and awkward, we want to think clearly and work clearly, and this is why we want to surround ourselves with clear, straightforward things. ${ }^{27}$

The above quotation is taken from a speech read by Georg von Schnitzler, German commissar general, at the 1929 Barcelona International Exposition. In this speech, presented at the opening of the official German Pavilion, he summed up the image of Germany that he wanted to convey to the world: "maximum simplicity and maximum depth.... Our desire is to be absolutely truthful, to pay attention to the spirit of the new era whose sign is this: sincerity." 28 Judging by their dogmatic tone, universalizing statements, and content, von Schnitzler's words could well have been borrowed from any manifesto about avant-garde architecture in that period. The Electric Utilities Pavilion designed by Mies aligned with this statement of the German government's intentions.

The pavilion was a three-quarter cube, exactly 20 meters long, 20 meters wide, and 15 meters high (Figure 12). ${ }^{29}$ It was 
Figure 10 Dragisa Brasovan, Yugoslav Pavilion, Barcelona International Exposition, 1929 (photo by Pérez de las Rozas; Arxiu Fotogràfic de Barcelona; (C) Arxiu Fotogràfic de Barcelona).

Figure 11 Regino Borobio, CSHE (Ebro Water Authority) Pavilion, Barcelona International Exposition, 1929 (photo by Gaspar-Sagara and Torrents; Josep Maria Sagarra i Plana collection, Arxiu Nacional de Catalunya; @ Generalitat de Catalunya).
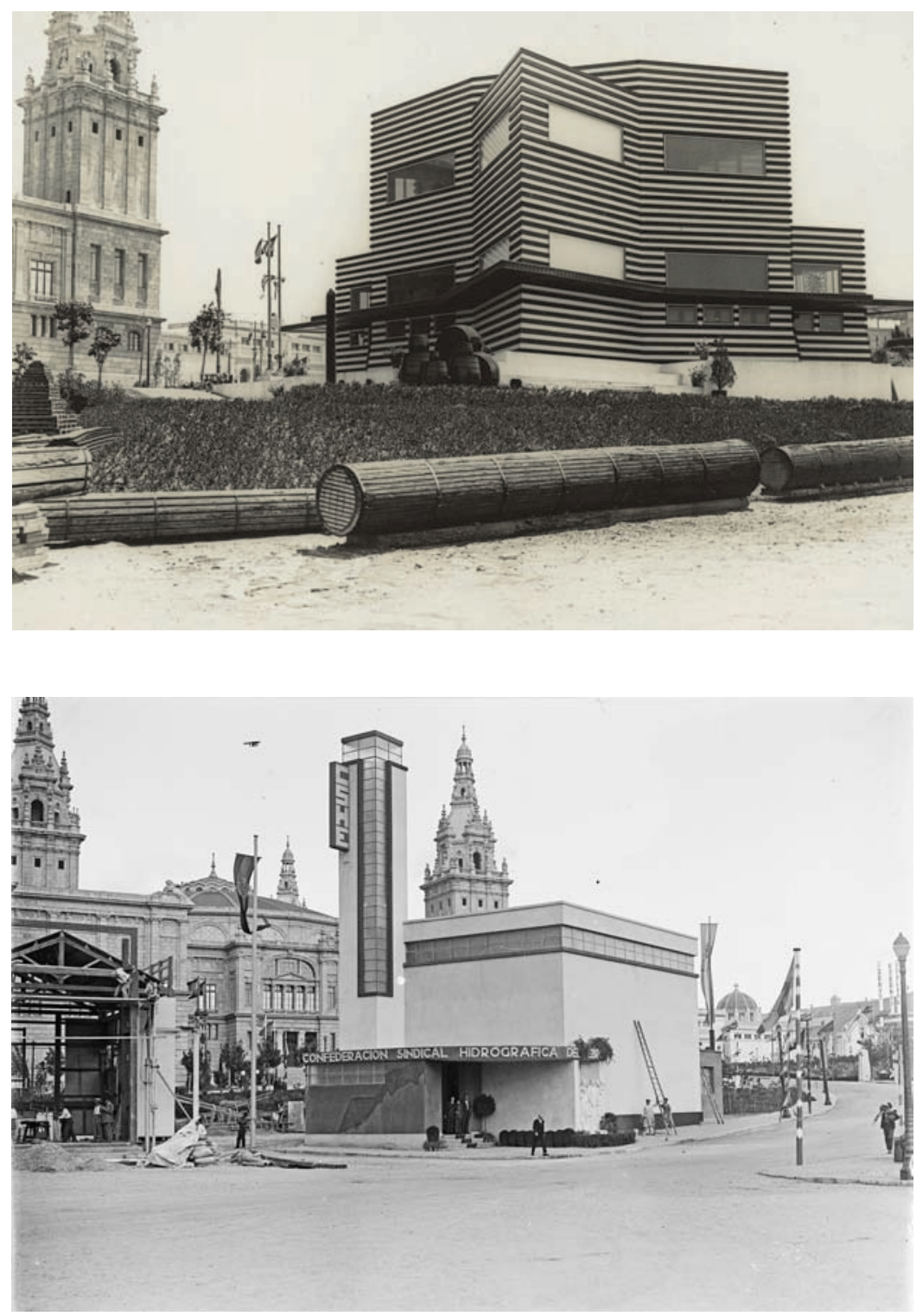

simple, emphatic, and streamlined, with an autonomy springing from its clear geometry. Unlike other creations by Mies, the pavilion sat directly on the ground, with no intermediate plinth or podium to detract from the building's ideal shape, singularity, simplicity, and oneness. The opaque nature of the cuboid was obvious because it was a closed container with almost no openings except the doorway, plus the small ventilation holes along the top on two opposite sides, which emphasized the solidity of the building. It had no glass façades, nothing shiny, no reflective or transparent elements.

Most of the trade pavilions were located on Avinguda dels Montanyans, but the Electric Utilities Pavilion was situated on the lower part, in the corner of the exhibition center on Plaza de la Luz (Figure 13). ${ }^{30}$ It was built between two of the exposition's most important buildings: the Communications and Transport Palace and the Textile Industry Palace. As a result, the Electric Utilities Pavilion was almost completely hidden and therefore almost completely overlooked by the press, architects, and the general public. In addition, the cube's simple, understated design and its abstract, neutral, and solid nature, which were so unlike the spectacular forms of other buildings, did nothing to make the pavilion stand out in the exposition.

The solidity of the cube's form was evident on each of its façades (Figure 14). The main façade had a single opening: a large entrance/exit that was wider than it was high and faced the Torre de la Luz (Figure 15). The two lateral walls were identical to each other. The clean lines of the large white faces that constituted these lateral walls were interrupted only by four vertical I beams, arranged like pilasters sticking out of each side wall, and eighteen square holes (measuring 40 centimeters along each side) almost at the top of the building, all of which were insignificant because of their size and the ratio of the openings to the wall. ${ }^{31}$ Indeed, the rather 


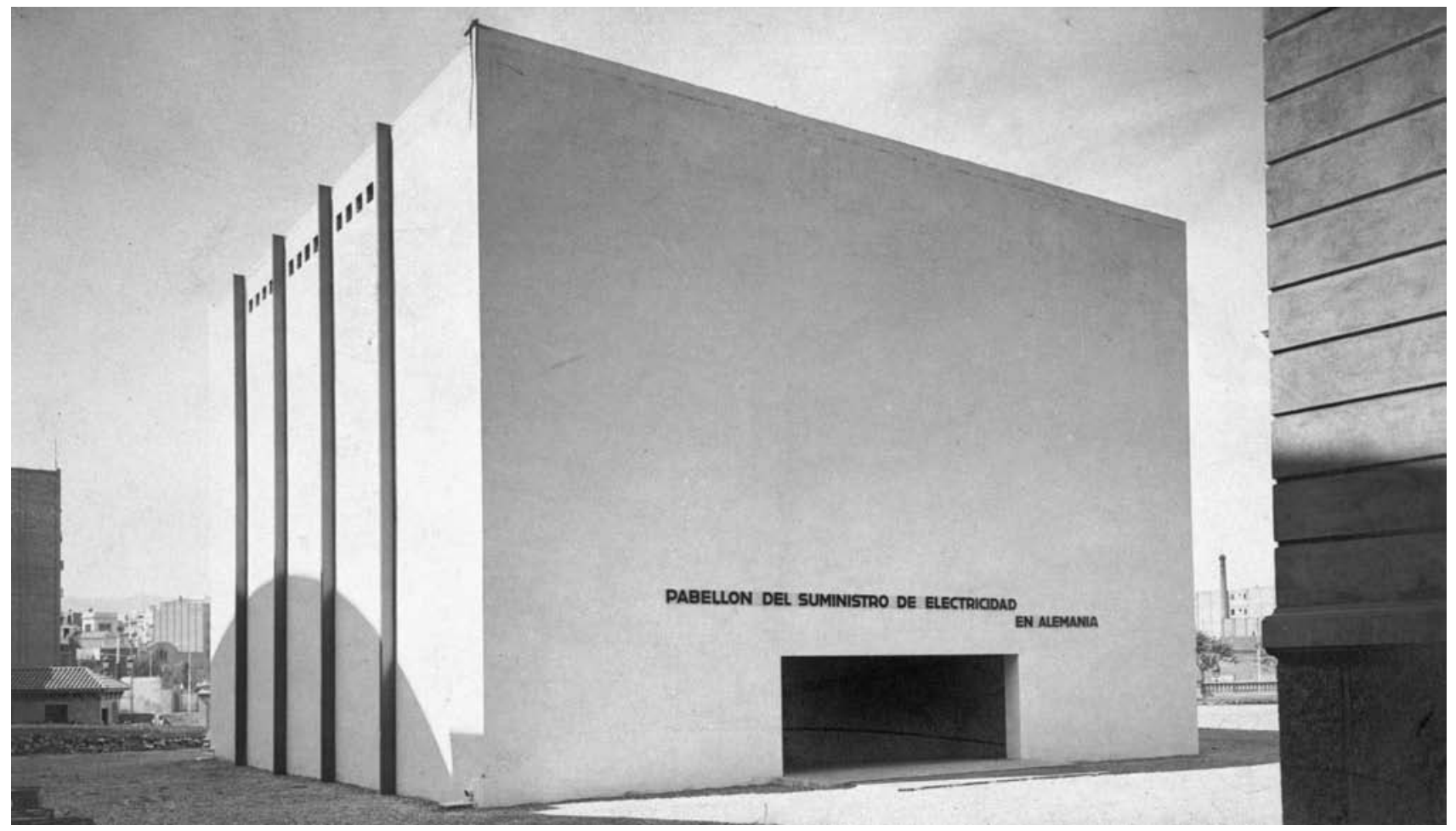

Figure 12 Ludwig Mies van der Rohe, Electric Utilities Pavilion, Barcelona International Exposition, 1929 (photo by Berliner Bild-Bericht; (c) Bildarchiv Foto Marburg).

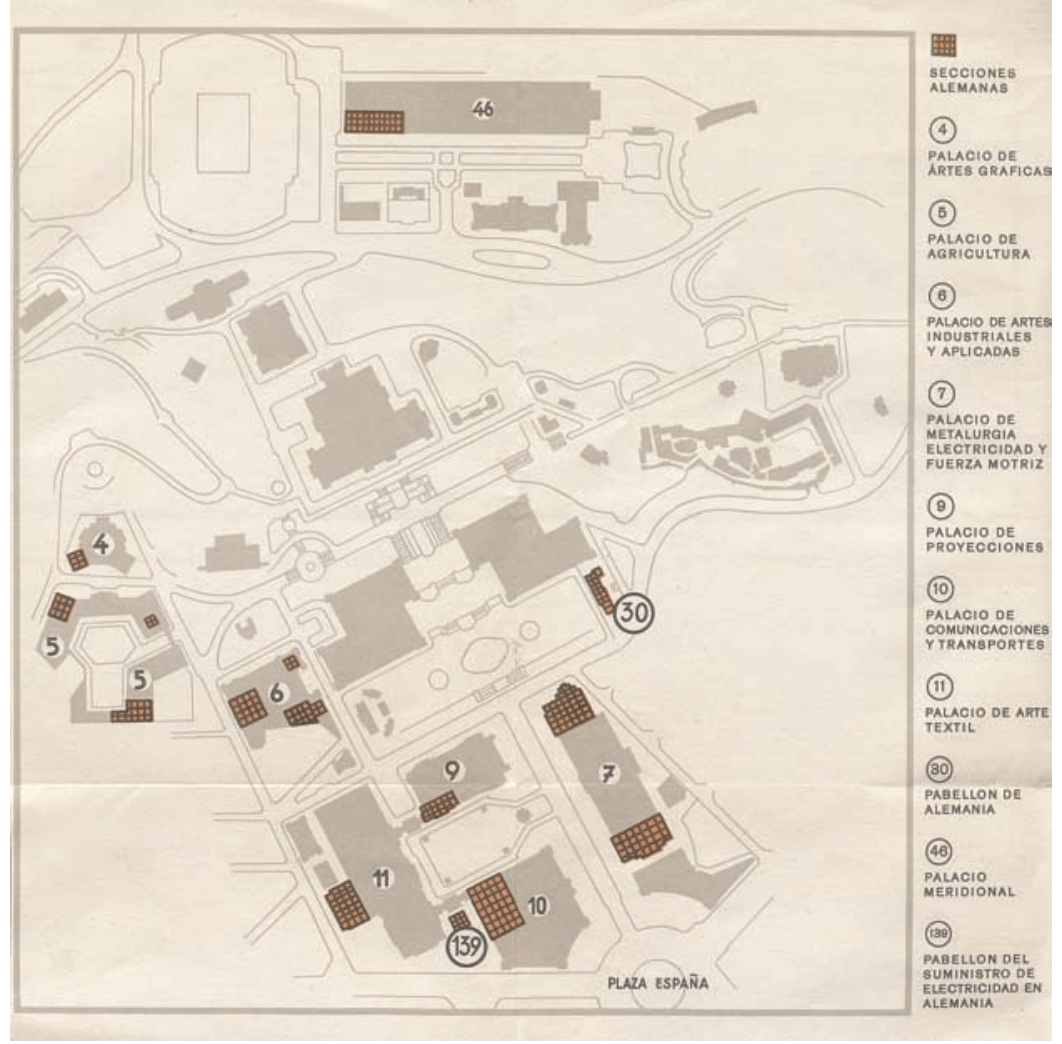

Figure 13 Official catalogue of the German section, locations of German exhibits, Barcelona International Exposition, 1929: 4, Palace of Graphic Arts; 5, Palace of Agriculture; 6, Palace of the Industrial and Applied Arts; 7, Palace of Metallurgy; 9, Palace of Projections; 10 , Palace of Communications and Transport; 11, Palace of the Textile Industry; 30, German Pavilion; 46, Southern Palace; 139, German Electric Utilities Pavilion (Exposición Internacional de 1929, Arxiu Històric Ciutat de Barcelona; @ Arxiu Històric Ciutat de Barcelona). 

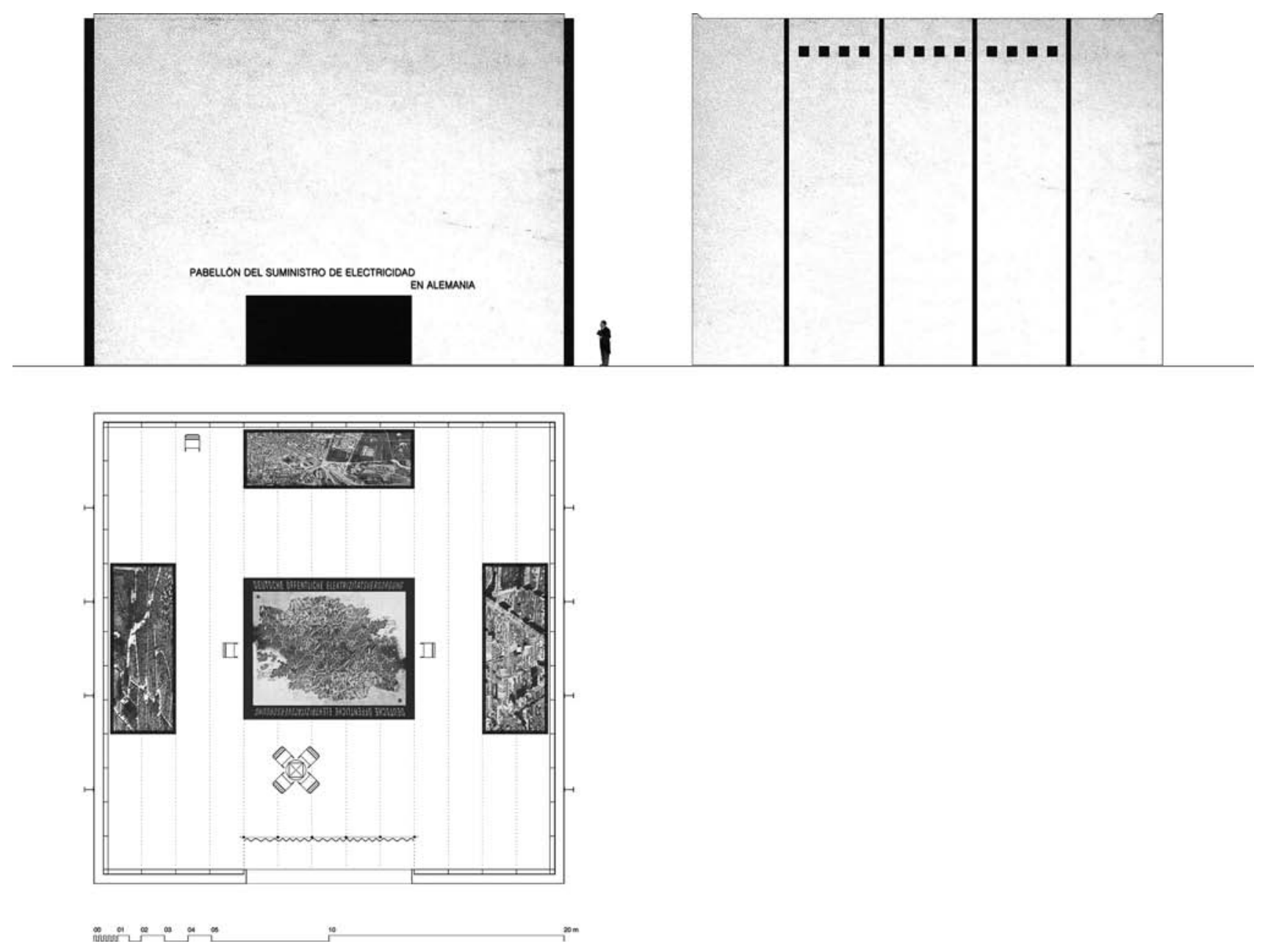

Figure 14 Ludwig Mies van der Rohe, Electric Utilities Pavilion, Barcelona International Exposition, 1929, reconstruction of the floor plan and the main and lateral elevation (author's drawing).

extreme proportions of this solid-void ratio emphasized the solidity of the pavilion. This Miesian opaque box was one of the buildings designed separately and not in connection with its surroundings, situated as an afterthought on a site where any building would be overshadowed by the vast palaces in its vicinity. Something very similar happened to the CSHE (Ebro Water Authority) Pavilion (see Figure 11). This building, situated at the beginning of Avinguda dels Montanyans and alongside the National Palace, was designed in keeping with its own concept and message. ${ }^{32}$ This pavilion's function, subject matter, and outer appearance resembled those of Mies's opaque cube. It consisted of a white prism with a fenetre en longueur, or ribbon window, a tower in the shape of a milestone bearing the company's logo, and an entrance canopy, all in keeping with avant-garde architecture. ${ }^{33}$ Like the Electric Utilities Pavilion, it was simply a container for functional space, and its external appearance was the outcome of

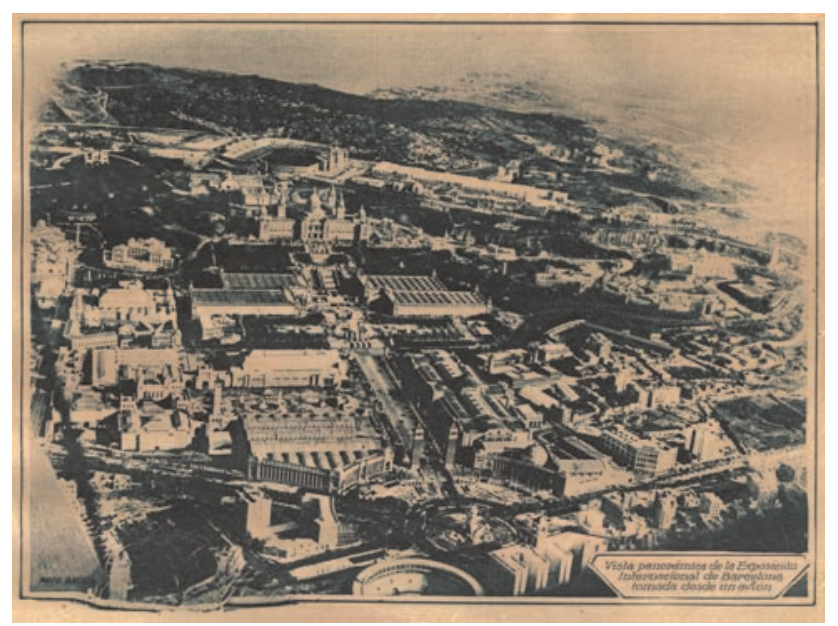

Figure 15 Aerial view of the palaces and pavilions, including the Electric Utilities Pavilion, during the Barcelona International Exposition, 1929 (photo by Josep Badosa). 
its functional requirements. It was an ephemeral, decontextualized building designed to cater to its interior space; it communicated the spirit of engineering and industrial manufacturing and the importance of the product on display.

Unlike the outer walls of Mies's Barcelona Pavilion, those of the Electric Utilities Pavilion were built not of refined materials but of brick with lime plaster. Although it seems contradictory for an ephemeral building to be made of brick, it happened on more than one occasion in Mies's work. In his projects for the German pavilions at the 1934 Brussels International Exposition and the 1929 Barcelona Exposition, Mies used heavy, durable materials combined with the incipient technology of glass and steel.

If an exhibition pavilion is the ideal building for experimentation, why did Mies design this one in the form of an opaque box with plain, white outer walls? At the Weissenhof Housing Estate, Mies, the exhibition director, stipulated just two requirements for the residential units: flat roofs and pale colors for outer walls. ${ }^{34}$ Although these traits may seem novel, they were already being used by some of Mies's contemporaries. Le Corbusier, who designed two buildings for the Weissenhof Housing Estate, had coined what he called the "Law of Ripolin" in 1915, in which he reflected on the role of white walls in architecture. ${ }^{35}$ White façades eliminated everything superfluous and emphasized what was essential, focusing attention on the object. As Mark Wigley puts it: "Whitewash frees visuality. ... The true status of the object is stripped of its figurative masks and emerges simply in its purest form, transparent to the beholder." 36

The only element in the Miesian opaque pavilion that might distract the beholder from that streamlined view was the visible metal structure. Four identical steel columns cast the only shadows on the taut white surface of the cube's two side walls, dividing each one into five equal parts (see Figure 12). Once again, in parallel with Mies's block of flats on the Weissenhof Housing Estate in Stuttgart, the modernist metal structure not only supported the building and relieved its outer walls of their load-bearing function but also dictated the modular unit of the façades. Mies endowed the interior of the Electric Utilities Pavilion with a freestanding space by moving the structure-consisting of the front and back brick walls and eight steel columns (four along each side wall) outward to the perimeter of the building (see Figure 14). The outcome was a 20-meter-span portal frame consisting of six parallel transverse frames 4 meters apart, the outer two being the front and rear brick walls and the intermediate ones being the metal columns.

Several of these stylistic and formal considerations have caused Josep Quetglas to compare the Electric Utilities Pavilion with the outer shell of Peter Behrens's AEG Turbine Factory, which Behrens designed when Mies was working in his studio. ${ }^{37}$ For example, Quetglas notes each building's unit volume, the different appearance of the front and side façades, the regularly spaced bare steel columns, and the sign bearing the building's name. Despite these similarities, however, the two buildings have considerable differences. Whereas the turbine factory was a modern version of a Greek temple, with its stylobate intermediate section flanked by side columns, pediment, and cornice, the Electric Utilities Pavilion featured none of these elements. The underlying concept of the Miesian opaque pavilion was an abstract box with no classical hierarchy in which, as mentioned above, the columns in the structural frame were shifted to the outer perimeter for one purpose alone: to create a large, open space. It was a cuboid designed to create an inner space, a cuboid whose neutrality was interrupted by lettering alone. It was the only trade pavilion at the exposition with no company logo on the outside. ${ }^{38}$

Mies had used lettering two years earlier to highlight the Linoleum Werke Room, a hall he designed for Deutsche Linoleum-Werke (DLW) in Stuttgart. He set the words on two lines aligned with the right-hand doorpost-the same layout he used for the Electric Utilities Pavilion (Figure 16). While working on the Electric Utilities Pavilion, Mies also experimented with lettering on two business premises: his unrealized project for the Adam Department Store and a small pavilion built for the Leipzig Spring Fair (1929), yet another project commissioned by DLW (Figure 17). ${ }^{39}$ Like the Electric Utilities Pavilion, this trade fair stand was a geometric volume, aesthetically dependent on its advertising lettering, that aimed for the flexibility permitted by a free-span interior space. Unlike the Electric Utilities Pavilion, however, the Leipzig DLW stand was not opaque. Although the two buildings were both built directly at ground level, the glassfronted ground floor of the Leipzig stand created an indoor-outdoor link that Mies avoided in the Electric Utilities Pavilion. In Barcelona, what really mattered was the interior of the magic box; it was arranged so that everything inside would be surprising, stunning, and novel.

\section{An Empty Interior Shell}

The interior of the pavilion was a large box, the walls of which were covered with nothing but photos of Germany's electrical industry (Figure 18). Wilhelm Niemann took credit for the work done on the interior murals and photographs, and also claimed years later that he had helped build the pavilion, but no evidence has been found of any acknowledgment by Mies that might confirm such work by Niemann. ${ }^{40}$ Confirmation of the contribution made by Fritz Schüler, on the other hand, does exist. According to correspondence between Schüler and Mies, Schüler, an engineer, helped Mies design the pavilion interior. In a letter dated 13 March 1933, Schüler asked Mies to certify his participation in the Electric Utilities Pavilion. ${ }^{41}$ 
Figure 16 Ludwig Mies van der Rohe and Lilly Reich, Linoleum Werke Room, The Dwelling exhibition, Stuttgart, 1927 (○) 2017 DLW Flooring $\mathrm{GmbH}$ ).

Figure 17 Ludwig Mies van der Rohe, Deutsche Linoleum-Werke AG display, Leipzig Spring Fair, 1929 (@ 2017 DLW Flooring GmbH).

Figure 18 Ludwig Mies van der Rohe and Fritz Schüler, interior of the Electric Utilities Pavilion, Barcelona International Exposition, 1929 (photo by Berliner Bild-Bericht; ( ) Mies van der Rohe, VEGAP, Spain, 2017).
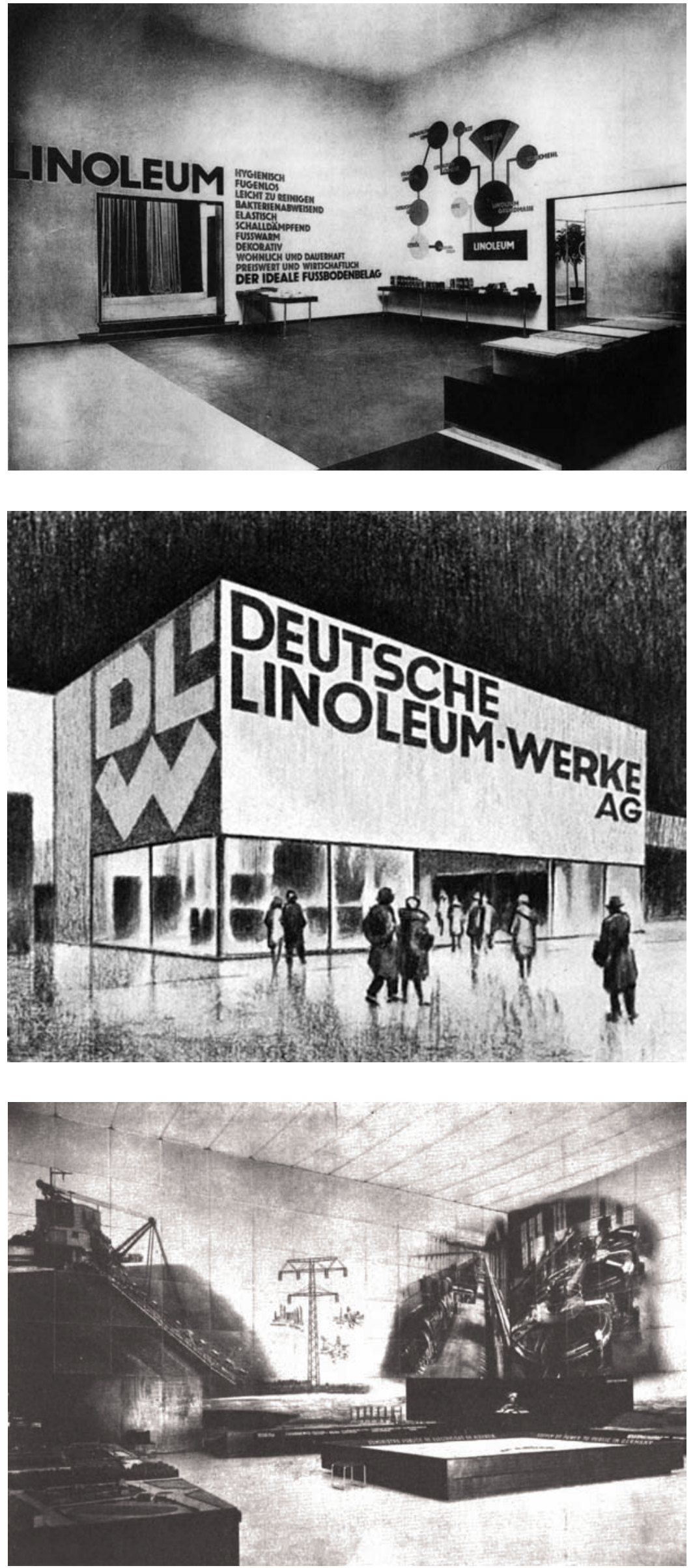
Mies replied in writing five days later, thanking Schüler for his work on the project. ${ }^{42}$

Mies and Schüler created a seamless spatial and physical scenario inside the pavilion. The spatial continuum was the result of the open plan, with no walls or partitions inside. In visual terms, just two materials could be seen: the linoleum covering the floor and the material lining the walls, on which the photographs were printed. Printed images covered the walls entirely, hiding not only the materials from which the walls were constructed but also the spatiality of the cuboid itself. The cleverly arranged images seemed to make the outer walls disappear.

The nature of the material on which the photos were printed is not specified in any archival documents. Judging by an indoor snapshot (see Figure 18) and Mies's work on his earlier exhibitions, it may have been fabric stretched across a frame. Mies had used textile strips two years earlier on the ceiling of the Glass Room and the walls of the Velvet and Silk Café. These were the first halls that Mies designed in association with Lilly Reich and the first Miesian spaces featuring fabric as an architectonic element. They were followed by more textile installations by Mies and Reich, such as the German textile exhibit in the Barcelona industrial section, which the two designed in parallel with Mies's work on the Electric Utilities Pavilion.

Although Reich showed Mies the potential of textiles, the use of such materials not only to clad but to shape spaces already had a long history. ${ }^{43}$ As Adolf Loos states in "Das Prinzip der Bekleidung," textiles reveal their own meaning when they clothe walls. ${ }^{44}$ Loos believed that when fabrics are used to cover a surface, they should remain true to their inherent nature and not imitate the underlying surface in an attempt to pass themselves off as something they are not. In this instance, the outer shell of the pavilion and its metal columns and façades did not affect the interior of the pavilion; they merely served to provide a perfectly flat surface. Once the flatness of the container was assured, everything was ready for the fabric - printed fabric in this instance-to be installed. Inside the pavilion, the textiles were what really mattered.

Fabric on the walls and the ceiling shaped the interior of the pavilion and molded the container into square units, as can be seen in the view of the interior (see Figure 18). The photos continued around the corners of the building, removing the impression of a delimited inner space. ${ }^{45}$ Their seams modulated the canvas, although the grid that could be seen on the walls and ceiling gave the impression of a seamless whole that created spatial effects and depth. The plain, horizontal ceiling hid the structure of the roof while filtering the light emitted by fixtures above the fabric ceiling scrim. The walls were like enormous advertisements covered in fabric with an artificial landscape of images printed on it. It was a landscape that softened the cuboid's geometry by blurring the edges, dihedral angles, and planes in a spatial illusion. Just as this Miesian montage sought to project spectators into a real scene, so the printed photographs allowed spectators to enter re-created and unusual places not normally seen or that could be captured only by new devices able to transform the real world into images. ${ }^{46}$

As a member of avant-garde movements in Germany and as director of Werkbund exhibitions from 1923, Mies was familiar with the technique and media impact of photography. ${ }^{47}$ He was also well versed in New Objectivity photography and its stunningly beautiful portraits of Germany's booming industry that transformed factories into veritable landmarks of New Architecture. No photograph of the building is to be seen in the catalogue of the Electric Utilities Pavilion; the aim of the catalogue seems to be to convey an engineer's view of the architecture of Germany's power plants. Aware of the possibilities of this new technology, Mies used printed photos in subsequent exhibitions, including German People/German Work, held in Berlin in 1934, and the solo exhibition of his own work held at New York's Museum of Modern Art in 1947. On 12 March 1938 Mies patented his "Method for Printing Wallpaper," created in conjunction with Walter Peterhans and brought to fruition thanks to Lilly Reich's determination. ${ }^{48}$

Hidden within the Miesian opaque pavilion was a threedimensional panorama that represented a distant world. As if inside a museum or theater, visitors to the exhibition discovered the industrial landscape that characterized the age of the machine and progress. Enlarged, continuous photographs spanning apexes and edges concealed the outer walls of the building, transforming it into a magic lantern showing a theater stage on which reality and fantasy were ambiguously acted out. Far from pursuing the harmonious external proportions of this square cuboid pavilion, the interior became a decidedly horizontal space recognizable thanks to the modulation of the fabric. In the photo of the interior, in which the modules are clearly visible across the length and width of the space, the space reads as horizontal (see Figure 18). I believe Mies's idea was not to emphasize the cube's internal geometry but to stress the box defined by the fabric and its images, which was able to decorate a pure, white, undifferentiated space and transform it into a completely different space, exploiting the interplay of contrasting interiors and exteriors used since the dawn of architecture. ${ }^{49}$ To achieve this, he reduced the ceiling height and turned the pavilion into a theater with a rigging system (Figure 19), a polyhedral theater not unrelated to Frederick Kiesler's experimental set design, Walter Gropius's Total Theater, and the theater of Erwin Piscator, with its belief in human behavior and capacities. The interior of the pavilion was illuminated by means of overhead lights hidden in the ceiling. The fabric layer diffused the artificial light evenly, giving the scene 


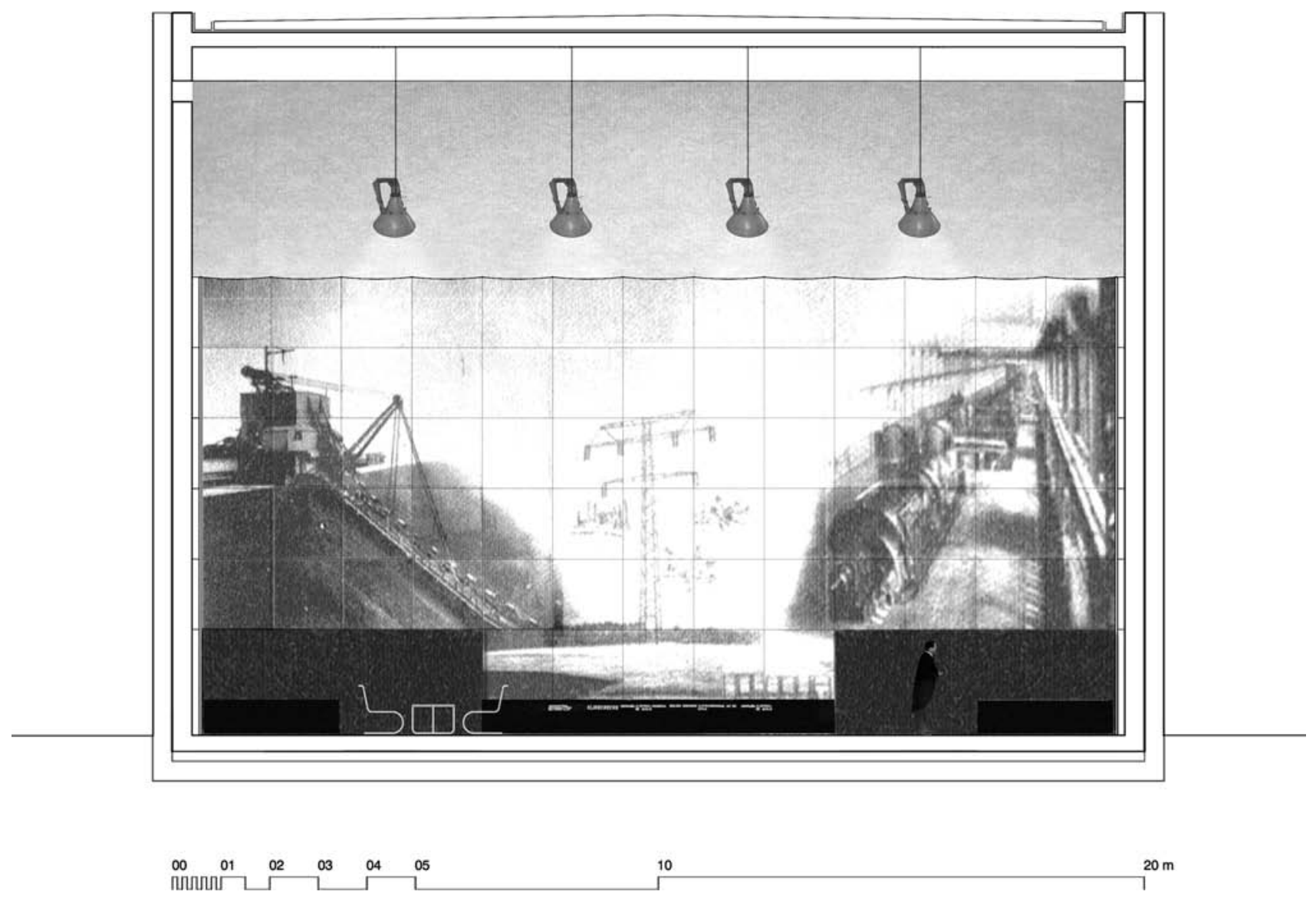

Figure 19 Ludwig Mies van der Rohe, Electric Utilities Pavilion, Barcelona International Exposition, 1929, reconstruction of the cross section (author's drawing).

an impression of ethereal clarity. Like a theater, the opaque box was hermetically sealed: the sixteen holes in the lateral walls were vents for the heat and condensation given off by the spotlights mounted above the ceiling. The resemblance to a theater was also apparent in the way the photographs were displayed, toying with the deliberate contradiction of exhibiting an outdoor landscape inside a closed box.

The pavilion experimented with the relationship between the void in the box, defined by its own outer walls, and the material nature of the box's perimeter. It was a building that, instead of exhibiting the outside world through transparent glass, transformed itself into a world disguised by the photographs covering the interior's brick-and-lime-mortar walls. The "exhibited image" was the "image of the exhibition," the pavilion's distinguishing brand or label. The cover of the official catalogue designed by Franz Peffer features not the building but a fragment of the image stamped on the fabric walls: an electricity pylon beaming light onto the name of the pavilion and lighting up the world at its feet (Figure 20). The text inside does not provide information about the building. The only mention of the pavilion is a short description of the exhibits on display. ${ }^{50}$ In any case, the electricity pylon was the company's icon, a landmark summing up the message: the scale, power, and scope of this new source of energy. Inside the pavilion, the pylon was depicted in the middle of the fabric wall, merged with the exhibits, including mock-ups, maps, and Miesian tubular furniture. The background and the object created an atmosphere in which physical reality blended with the projected scene.

We know about the layout and dimensions of the mockups thanks to three pictures of the pavilion's interior and an article published in the Spanish daily La Vanguardia, which describes in depth the subject matter of each mock-up and the images printed on textiles (Figure 21). ${ }^{51}$ The images in Mies's montages tended to be clustered in the corners, leaving empty areas in the middle. This drew visitors' attention to the mock-ups arranged symmetrically along each side. In addition, the lower parts of walls in the corners were the only places in the pavilion where there were no images or mockups. These wall surfaces were simply painted black. It was in these dark areas that visitors were free to wander about, a stagelike place once again where actors could appear and disappear. $^{52}$ 

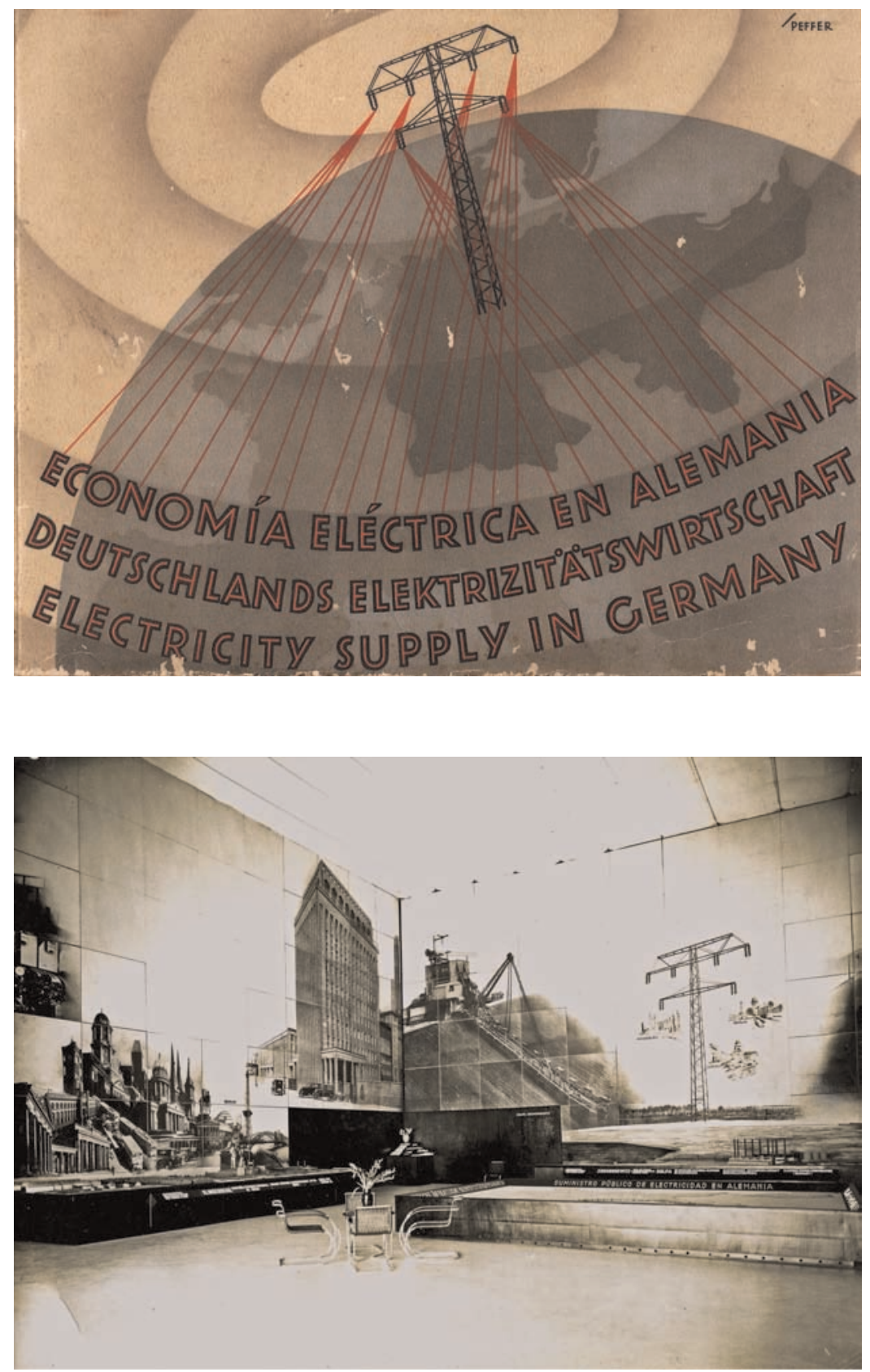

Figure 20 Franz Peffer, cover of the official catalogue for the Electric Utilities Pavilion ( $L a$ Economía Eléctrica en Alemania/Deutschlands Elektrizitätswirtschaft/Electricity Supply in Germany [Leipzig: Druck der Spamerschen Buchdruckerei, 1929]).

Figure 21 Ludwig Mies van der Rohe and Fritz Schüler, interior of the Electric Utilities Pavilion, Barcelona International Exposition, 1929 (photo by Berliner Bild-Bericht; $\odot$ Mies van der Rohe, VEGAP, Spain, 2017).

\section{Conclusion}

In the Electric Utilities Pavilion and subsequent projects, Mies used the visual effects of geometry, graphics, mural photos, and the position of objects to create a virtual reality inside enclosed, prismatic spaces able to make spectators experience new sensations. The architecture he created was not an "image of architecture" but what I call an "architecture built of images," an architecture not intended to be a sculptural object, but one that creates space in itself, that envisions architectural space as an encounter between inside and outside, the self-contained and the expansive. This is an architecture that, in keeping with Neumeyer's approach, pursues the humanist ideal of giving us a framework in a built space that has a close-knit relationship with our perception and imagination. ${ }^{53}$ Although Mies's idea for the pavilion was to create a low-key building, the outcome was quite the opposite: a "magic box" in which the eye of the beholder shaped a special industrial landscape.

In the Electric Utilities Pavilion, Mies discarded ideas, experimented, and made discoveries. First, he sidelined certain concepts, never to use them again. Never again would he build opaque white cubes or other buildings directly on the ground. Second, it was in Barcelona that he streamlined his concepts and experimented with contrasts, 
building a national pavilion and a trade pavilion at opposite ends of the architectural spectrum: open versus closed space, flatness versus volume, daylight versus indoor lighting, subdued versus eye-catching materials, interior metal structure versus exterior metal structure, centrifugal space versus centripetal space, fact distorted by reflections and fiction aspiring to reality. And third, it was here that Mies discovered architectural principles that were to mark his subsequent work. Whereas the Barcelona Pavilion is an exercise in locating outer walls in relation to columns, the Electric Utilities Pavilion represents the first time in Mies's work that structure and outer walls are both shifted outward to the building's perimeter, in what Wallis Miller regards as a forerunner of the studs in contact with the outer walls of his American buildings. ${ }^{54}$ It was also the first time that Mies used photo murals to create the materiality of the interior of a building, in this case an industrial style that subsequently evolved into his artistic interwar architecture and culminated in the Convention Hall project. ${ }^{55}$ The multistrata montage of the Convention Hall project reflected the concepts of interest to Mies in his final phase: materials, society, and structure. It was in the Electric Utilities Pavilion that Mies timidly experienced for the first time his longed-for isotropic, democratic "universal space" with no columns, which Neumeyer describes as "a space open on all sides with no columns in the middle," in which the indoor photographs "joined together to create a three-dimensional panorama that opened space up toward an imaginary horizon." 56

The information I've gleaned about this pavilion over years of research has been frustratingly scant but sufficient to enable me to interpret the building graphically. Hypotheses have fallen into place. I have been able to translate literature and photography into lines, the universal language of architecture. And I have gradually managed to re-create the missing drawings of what seemed at first to be a rather insignificant trade pavilion. But this was no ordinary trade pavilion. Mies's opaque cube was actually a life-size workshop where the architect experimented with novel concepts, some of which became key features of his subsequent work. It is my hope that these drawings and this article will enable Mies's opaque cube to emerge from relative obscurity, after decades overshadowed by the emblematic and eye-catching palaces of the 1929 Barcelona International Exposition, and claim its rightful place in his built legacy.

Laura Lizondo Sevilla has degrees from the Universitat Politècnica de València, Spain, where she has taught since 2008. She has been a visiting scholar at Columbia University (2011) and Central Saint Martins, University of the Arts London (2015). She is managing editor of En Blanco: Revista de Arquitectura. Her current research examines British "plateglass universities" of the 1960s. laulise@pra.upv.es

\section{Notes}

1. This article is an offshoot of my $\mathrm{PhD}$ dissertation "¿Arquitectura o exposición? Fundamentos de la arquitectura de Mies van der Rohe" (Architecture or exhibition? The foundations of Mies van der Rohe's architecture) (2012). My most grateful thanks to my doctoral advisers, José Santatecla Fayos and Ignacio Bosch Reig, for their invaluable guidance, and to Anne Barton de Mayor, for her help with translation of the manuscript for this article.

While I refer to the pavilion as a cube, the shape of the building was not a perfect cube but a square cuboid.

2. Fritz Neumeyer, "A Return to Humanism in Architecture," in Hans Kollboff: Architektur=Architecture (Munich: Prestel Verlag, 2002), 24.

3. Fritz Neumeyer, La palabra sin artificio: Reflexiones sobre arquitectura 1922/ 1968 (Madrid: El Croquis Editorial, 1995). This work by Neumeyer was originally published in German as Mies van der Rohe: Das kunstlose Wort: Gedanken zur Baukunst (Berlin: Siedler Verlag, 1986); it appeared in English as The Artless Word: Mies van der Rohe on the Building Art (Cambridge, Mass.: MIT Press, 1991).

4. Neumeyer, "A Return to Humanism in Architecture," 20.

5. In the early 1920s, when Mies was immersed in avant-garde circles, he tested the properties of the materials typical of New Architecture in his "paper buildings," or unbuilt projects, many of which were named after the proposed building materials. These included the Friedrichstrasse Skyscraper (1921), the Glass Skyscraper (1922), the Concrete Office Building (1923), the Concrete Country House (1923), and the Brick Country House (1924). These unbuilt works and associated writings were the first manifestos in which Mies expressed his interest in the formal and visual impact of materials. The exhibitions in which Mies participated as an architect were, in chronological order, The Dwelling and the Weissenhof Housing Estate (both Stuttgart, 1927), Women's Fashion (Berlin, 1927), the 1929 Leipzig Spring Fair, the 1929 Barcelona International Exposition, The Dwelling in Our Time (Berlin, 1931), the 1934 Brussels International Exposition, German People/German Work (Berlin, 1934), and the 1937 Imperial Exposition of the German Textile and Garment Industry in Berlin.

6. Few critics have shown any interest in this pavilion. Ignasi Solà-Morales provides a few interesting details about the Electric Utilities Pavilion, such as the dimensions: Ignasi Solà-Morales, L'Exposició Internacional de Barcelona, 1914-1929: Arquitectura i ciutat (Barcelona: Fira, C.L., 1985), 120. Josep Quetglas compares it to the AEG Turbine Factory designed by Peter Behrens when Mies worked in Behrens's studio: Josep Quetglas Riusech, "Pérdida de la síntesis: Pabellón de Mies," Carrer de la Ciutat, no. 11 (1980), 17-27. Fritz Neumeyer emphasizes the interior quality of the pavilion: Neumeyer, $L a$ palabra sin artificio, 344. Finally, a contribution made by Wallis Miller deserves a special mention: see Wallis Miller, "Mies and Exhibitions," in Mies in Berlin, ed. Barry Bergdoll and Terry Riley (New York: Museum of Modern Art, 2001), 338-50. Although Miller does not analyze the Electric Utilities Pavilion in depth, her very pertinent contribution provides details about the structure. She describes the columns as four I beams on the outside, a characteristic that leads Miller to regard the structure of this pavilion as the beginning of Mies's tendency to shift structures and façades outward to the edges of buildings and as a forerunner of his buildings in the United States, such as the Seagram Building and the Farnsworth House.

7. Diario Oficial de la Exposición Internacional de Barcelona 1929-1930, various issues, Press and Magazines room, National Library of Spain, Madrid.

8. La Economía Eléctrica en Alemania/Deutschlands Elektrizitätswirtschaft/ Electricity Supply in Germany (Leipzig: Druck der Spamerschen Buchdruckerei, 1929).

9. Ludwig Mies van der Rohe, "Ludwig Mies van der Rohe: My Address of Appreciation," interview by Henry Thomas Cadbury-Brown, Architectural Association fournal 75, no. 838 (July/Aug. 1959), 27-28. 
10. According to Dietrich Neumann, the Barcelona Pavilion was not built for political reasons, but rather on account of the determination and commitment of the German commissioner Georg von Schnitzler. The German government "firmly stated that while German industry should be present in Barcelona, there was no need and there were no funds for the small 'representative pavilion' that the Spanish delegates had suggested. Georg von Schnitzler . . . despite the clear government directives against it, and without available funds, promised the Spanish organizers a separate German pavilion, and commissioned Mies to design it." Dietrich Neumann, "Politics and Architecture: Mies van der Rohe's German Pavilion at the 1929 International Fair in Barcelona" (paper presented at the conference "Las exposiciones de arquitectura y la arquitectura de las exposiciones," Pamplona, 7-9 May 2014), 516. In addition, von Schnitzler and his wife paid for the pavilion out of their own pocket, as shown by a letter to an unknown addressee from Ritter of Germany's Foreign Affairs Ministry in Berlin, 12 Oct. 1932, Politisches Archive, Bundesarchiv, Berlin.

11. Mies was an expert in exhibition projects, but other hypotheses have been put forward concerning why he was chosen for the German buildings in Barcelona. According to Dietrich Neumann, it was Lilly von Schnitzler, a grand dame of Frankfurt society and an avid art collector and patron, who convinced her husband to hire Mies. Neumann, "Politics and Architecture," 517. Christian Lange, on the other hand, believes that Mies was hired because he was the architect chosen by Hermann Lange (for whom Mies had already carried out almost a dozen projects) to design all the exhibits representing the Krefeld silk industry - the first industry that decided to take part in the exposition and the one that spent the most on the presentation of its products. Christian Lange, Mies van der Robe and Lilly Reich: Furniture and Interiors (Ostfildern, Germany: Hatje Cantz, 2007), 14.

12. However, it was not until late April 1928 that Germany confirmed it would be taking part in the exposition: "Germany's participation in our exposition is now confirmed. I have no doubt that this news will have a considerable impact on the attitude and intention of other countries." Enrique Dominguez-Rodiño, Spanish ambassador to Germany, to Santiago Trias, organization and advertising manager, Barcelona International Exposition, 29 Apr. 1928, Arxiu Contemporani de Catalunya.

13. Lilly Reich studied with JosefHoffmann at the Wiener Werkstätte(Viennese workshops) from 1908 to 1920. Then she was a student of Else Oppler-Legband, "who had studied with Henry van de Velde, the architect and designer and one of the principal founders of the German Werkbund. When Reich became her student in fall 1910, she had begun teaching at the Die Höhere Fachschule für Dekorations-kunst, a school led by many of the individuals who became important colleagues throughout Reich's career, including Hermann Muthesius, Peter Behrens, and Richard L. F. Schulz." Matilda McQuaid, Lilly Reich: Designer and Architect (New York: Museum of Modern Art, 1996), 10. 14. Laura Lizondo Sevilla, “¿Arquitectura o exposición? Fundamentos de la arquitectura de Mies van der Rohe” (PhD diss., Universitat Politècnica de València, 2012).

15. The list of temporary exhibitions staged by Reich before 1926 is considerable. See Sonja Günther, Lilly Reich 1885-1947: Innenarchitektin, Designerin, Ausstellungsgestalterin (Stuttgart: Deutsche Verlags-Anstalt, 1988); McQuaid, Lilly Reich.

16. Andreas Marx and Paul Weber, "From Ludwig Mies to Mies van der Rohe: The Apartment and Studio Am Karlsbad 24 (1915-39)," in Mies and Modern Living: Interiors, Furniture, and Photography, ed. Helmut Reuter and Birgit Schulte (Ostfildern, Germany: Hatje Cantz, 2008), 35.

17. Correspondence with clearance office, box Barcelona Pavilion, folders 1-3, Mies van der Rohe Archive, Museum of Modern Art, New York.

18. McQuaid asserts that the Hackerbräu beer exhibit was a combined effort, while Günther believes that Mies and Reich worked together on the textiles and chemistry exhibits. McQuaid, Lilly Reich, 6; Günther, Lilly Reich 1885$1947,25$.
19. They had worked together on the design and construction of exhibitions previously - the Glass Room, the Linoleum Werke Room, and the Velvet and Silk Café. These exhibition displays were conceptually and physically quite similar to those in Barcelona, yet another indication that the latter were also the product of teamwork by Mies and Reich.

20. Reich's training enabled her to evolve into a skillful interior designer. Like Charlotte Perriand, Eileen Gray, and many other designers in the first half of the twentieth century, Reich designed each item and decor bearing in mind the precise spot for which it was intended-always a built place with set boundaries. But this specialization in the realm of interior design limited her architectural activities considerably. In fact, in her entire career, Reich built just one building: a detached house that was also part of a temporary setting. As Günther notes: "Lilly Reich had studied arts and crafts and had less practice in designing buildings. . . The drawings of the 'Ground-Floor Dwelling' that Reich designed for The Dwelling in Our Time were characterized by a stiff style that lacked the expert's architectural elegance, while Mies's house featured a highly developed spatial awareness." Günther, Lilly Reich 1885-1947, 37, my translation. Unless otherwise noted, all translations are my own.

21. Francisco Cañadas, "El Munjuich de antaño," Diario Oficial de la Exposición Internacional de Barcelona 1929-1930, no. 32 (Oct. 1929), 19.

22. Forestier, a town planner and forestry engineer, came to Barcelona to work for city authorities on a project to create parks, including one on Montjuic. This site, then on the outskirts of the city, was earmarked for the International Exposition of Electrical Industries, which finally developed into the Barcelona International Exposition. Thus, in keeping with Forestier's garden city concept, Montjuïc was transformed into an enormous green space, a place to promote well-being with leisure and recreation areas, connected to the existing city. Forestier distanced his proposal from English picturesque and French geometrization and couched it in the language of the fragmented cropland typical of the Mediterranean. The result was a mountain transformed not into one large park but into a series of interventions on different levels connected by avenues and walkways. Solà-Morales, L'Exposició Internacional de Barcelona, 45.

23. Noucentisme was a cultural and artistic movement that originated in Catalonia in the early twentieth century as a reaction to modernism. It was founded by a group of intellectuals and politicians whose ideas and projects sought to improve the country by means of concepts such as abstraction (the mastery of reality by the human will), imperialism (a desire for the interior hegemony of Catalonia), civility (the city as an image of a civilized country), classicism (concepts inspired by the Greco-Roman world), and Mediterraneanism (a return to the origins of Greek and Latin antiquity). 24. Solà-Morales, L'Exposició Internacional de Barcelona, 56.

25. The exhibition "palaces" built for the Barcelona International Exposition were the National (Spanish) Palace, the Palace of Communications and Transport, the Palace of Metallurgy, the Palace of Projections, the State Palace, the Palace of Modern Art, the Palace of Graphic Arts, the Palace of Agriculture, the Palace of the Industrial and Applied Arts, the Palace of Chemistry, the Palace of the Textile Industry, the Palace of the Missions, the Alfonso XIII Palace, the Victoria Eugenia Palace, and the Southern Palace. 26. Carolina García Estevez, "High and Low: Pabellones comerciales para la Exposición Internacional de las Industrias Eléctricas de Barcelona de 1929” (paper presented at the conference "Las exposiciones de arquitectura y la arquitectura de las exposiciones," Pamplona, 7-9 May 2014), 276.

27. Georg von Schnitzler, Diario Oficial de la Exposición Internacional de Barcelona 1929-1930, no. 12 (June 1929), 14.

28. Ibid.

29. Solà-Morales described the building as a "precise cube" exactly 18 meters long, 18 meters wide, and 18 meters high. Solà-Morales, L'Exposició Internacional de Barcelona, 120. Wallis Miller, however, mentions a "threequarter white cube, 15 meters high by 20 meters on each side," based on 
the description by Willy Lesser, "Der Deutsche Anteil an der Weltausstellung in Barcelona," Technische Rundschau, no. 30 (1929). Miller, "Mies and Exhibitions," 381.

30. "The arcade leads to the Plaza de la Luz, where Germany has built a peculiar cubic pavilion with straight, exceedingly simple lines intended to provide a convincing demonstration of its great hydroelectric industries and industrial power network." Eliseo Sanz Balza, Exposición Internacional de Barcelona 1929: Notas de un visitante (Barcelona: Talleres de la Tipografía Olympia, 1930), 140.

31. Miller, "Mies and Exhibitions," 344.

32. These two pavilions were not the only ones designed as inward-looking buildings that ignored the context of the exposition. The Calcetines Molfort's, Sociedad Anónima Uralita, and La Equitativa Pavilions did likewise—mainly because most of them were located not in the international section but on land left over after the palaces were built. In any case, the main aim of these buildings was not to blend in with their surroundings but to catch visitors' attention by means of vertical landmarks or slogans and entice them to enter the pavilions and view the products on display.

33. The building was designed by architect Regino Borobio of Saragossa, adviser to the CSHE. The January 1930 issue of the CSHE's magazine features a photograph and brief description of the pavilion: a building with straight lines, flat surfaces, no superfluous ornaments, and harmonious proportions. No mention is made of its interior. The only extant photograph of the interior fails to give an overall idea of the pavilion and merely shows white panels on which maps and mock-ups of the company are mounted, propped up against the walls. "La Confederación del Ebro en la Exposición de Barcelona," Revista de la Mancomunidad Hidrográfica del Ebro, no. 31 (Jan. 1930), 8.

34. Richard Pommer and Christian F. Otto, Weissenhof 1927 and the Modern Movement in Architecture (Chicago: University of Chicago Press, 1991).

35. Ripolin was a well-known brand of enamel paint invented in the late nineteenth century by the chemist Carl Julius Ferdinand Riep. In the 1920s, Le Corbusier often used Ripolin white enamel paint. His "Law of Ripolin" was a way of purifying form by applying an abstract coat of white paint. Le Corbusier, L'art décoratif d'aujourd'hui (Paris: Éditions G. Grès et Cie, 1925); translated by James Dinnet as The Decorative Art of Today (Cambridge, Mass.: MIT Press, 1987), ixi.

36. Mark Wigley, "La nueva pintura del emperador," Ra. Revista de Arquitectura, no.13 (June 2012), 8.

37. Quetglas Riusech, "Pérdida de la síntesis."

38. It is not clear which company funded this pavilion. However, judging by accounts dated 3 October 1929 of the amounts spent on the German pavilions and exhibitions, there can be no doubt that it did not receive funding from the German government. Account charges, exhibitors and contractors, 16 July 1929 to 26 Nov. 1929, box Barcelona Pavilion, folder 4, Mies van der Rohe Archive, Museum of Modern Art, New York.

39. There are no drawings or texts about this stand, just one photograph of the outside and several of the inside which appeared in the DLW news bulletin: "Die D.L.W. auf der Leipziger Frühjahrsmesse 1929," Nachrichten der Deutsche Linoleum-Werke AG, July 1929. This information is also available in the Deutsche Linoleum-Werke historic online archive (http://dlw.baunetz. de/sixcms/detail.php?id=454897) and in the catalogue DLW Reference Book 2, 255, http://pdf.archiexpo.es/pdf-en/armstrong-dlw/dlw-reference-book2/30-62012-_255.html (accessed 2 Feb. 2017).

40. Niemann's claim appears in a transcript of an interview filed in the Werkbund-Archiv in Berlin. See Claire Zimmerman, "Modernism, Media, Abstraction: Mies van der Rohe's Photographic Architecture in Barcelona and Brno (1927-1931)" (PhD diss., City University of New York, 2005). 41. Schüler to Mies, 13 Mar. 1933, correspondence from the Electric Pavilion, box Barcelona Pavilion, folder 10, item C, Mies van der Rohe Archive,
Museum of Modern Art, New York. Apart from the correspondence between Schüler and Mies, no other document confirms that they worked together. The official catalogue of the pavilion does not mention who designed the building; it provides only technical data and statistics about Germany's electrical industry.

42. Mies to Schüler, 18 Mar. 1933, correspondence from the Electric Pavilion, box Barcelona Pavilion, folder 10, item C, Mies van der Rohe Archive, Museum of Modern Art, New York.

43. Fabrics had already been used in architectural projects in the previous century to create spaces or cover the walls of preexisting spaces. Gottfried Semper's idea of using textiles as coverings and Otto Wagner's hanging curtains were studied and developed by architects such as Joseph Maria Olbrich and Josef Hoffmann, both of whom transformed and defined spatial boundaries by combining real and painted fabrics in different ways. Lilly Reich was familiar with all these techniques, having studied with Hoffmann at the Wiener Werkstätte. She began to work there with noble materials including textiles, becoming very fond of them as she learned to design using a language based on sophisticated and increasingly linear forms. Before starting work with Mies she had already experimented with the use of textiles in temporary spaces such as the staging of the exhibition Fashion Craft (Berlin, 1920) and the many stands she designed for the exhibition From Fiber to Textile (Frankfurt, 1926).

44. Adolf Loos, "Das Prinzip der Bekleidung," Neue Freie Presse, 4 Sept. 1898, translated as "The Principle of Cladding" by Jane O. Newman and John H. Smith in Adolf Loos, Spoken into the Void: Collected Essays 1897-1900 (Cambridge, Mass.: MIT Press, 1982), 66-69.

45. Miller, "Mies and Exhibitions," 344.

46. For details about Mies's montages and their considerable contribution to his work before and after the Barcelona International Exposition, see Martino Stierli, "Mies Montage," AA Files, no. 61 (2010), 54.

47. See Claire Zimmerman, Photographic Architecture in the Twentieth Century (Minneapolis: University of Minnesota Press, 2014).

48. The patent states the utility and purpose of this method: "a process for printing rolls of wallpaper using photographic templates in halftones and full tones and in the commercially standard graphic printing processes (relief, planography, intaglio) while maintaining the finest dotting as well as the customary prints colors. ... This invention makes it possible to produce wallpaper having entirely new effects, in particular unprecedented effects of depths." Patent number 158059, quoted in Dietrich Neumann, “. . . Wallpaper with Arctic Landscapes ... : Mies van der Rohe's Patents for Wallpaper Design and Printing Technology 1937-1950," in Reuter and Schulte, Mies and Modern Living, 265.

49. The Miesian opaque cube is based on a series of contrasts. A cubic, sealed, abstract, and heavy exterior contrasts with its horizontal interior, which embraces an imaginary landscape full of ambient suggestions (regarded as the opposite of abstraction), a seemingly lightweight interior-an impression heightened by the textile envelope. This wide range of contradictory effects bears out Mies's knowledge of the history of architecture, for contrasts between interiors and exteriors have been used since the times of early Christian architecture. There are many examples of the dichotomy of the simple exterior and inner richness of spirit dating from that period: the Baptistery of Constantine (Rome, AD 306-37), Santa Constanza (Rome, AD 350), the Basilica of San Stefano Rotondo (Rome, AD 468-83), and the Basilica of Saint Vitale of Ravenna (Ravenna, AD 526-47). Such opposites-that is, the contrast between a simple, abstract, plain exterior and an interior featuring a wealth of ornament, light, color, and illusory effects-are also found in Islamic buildings, such as the Alhambra in Granada. For more on this topic, see Ignacio Bosch Reig, Arturo Martínez Boquera, Margarita Fernández Gómez, and Luis Bosch Roig, "Espacio central en la arquitectura: Las claves de su permanencia," 
ARCHÉ: Publicación del Instituto Universitario de Restauración del Patrimonio de la UPV, no. 1 (2006), 177-90.

50. "A large relief map shows the interconnecting lines facilitating combined operation. The development is illustrated by illuminated charts. Steam and water power plants are shown in dioramas and giant photographs." La Economía Eléctrica en Alemania, 3.

51. "La Exposición Internacional: Pabellón de suministros eléctricos de Alemania," La Vanguardia, 1 Sept. 1929, 6.
52. Valentín Trillo-Martínez, "Traslaciones Miesianas/Miesians' Translations," Proyecto, Progreso, Arquitectura, no. 15 (Nov. 2016), 63.

53. Neumeyer, "A Return to Humanism in Architecture," 26.

54. Miller, "Mies and Exhibitions," 344.

55. Neil Levine, "The Significance of Facts: Mies's Collages Up Close and Personal," Assemblage, no. 37 (1998), 70-101.

56. Neumeyer, La palabra sin artificio, 344. 